\title{
Review \\ Direct cell-fate conversion of somatic cells: Toward regenerative medicine and industries
}

\author{
By Kenichi HoRISAWA ${ }^{* 1}$ and Atsushi SuzUKI*1,† \\ (Edited by Shinya YamanaKa, M.J.A.)
}

\begin{abstract}
Cells of multicellular organisms have diverse characteristics despite having the same genetic identity. The distinctive phenotype of each cell is determined by molecular mechanisms such as epigenetic changes that occur throughout the lifetime of an individual. Recently, technologies that enable modification of the fate of somatic cells have been developed, and the number of studies using these technologies has increased drastically in the last decade. Various cell types, including neuronal cells, cardiomyocytes, and hepatocytes, have been generated using these technologies. Although most direct reprogramming methods employ forced transduction of a defined sets of transcription factors to reprogram cells in a manner similar to induced pluripotent cell technology, many other strategies, such as methods utilizing chemical compounds and microRNAs to change the fate of somatic cells, have also been developed. In this review, we summarize transcription factor-based reprogramming and various other reprogramming methods. Additionally, we describe the various industrial applications of direct reprogramming technologies.
\end{abstract}

Keywords: direct reprogramming, cell-fate conversion, regenerative medicine, cell transplantation therapy, transcription factor, industrial application

\section{Introduction}

All cell types in the bodies of higher multicellular animals have extremely diverse phenotypes despite their genetic identity. A single zygote can divide and differentiate into a considerable number and wide variety of cells with unique genome sequences during development. The differences in the phenotypic characteristics among cell types result in different transcriptome and epigenome variations. As Waddington predicted in the $1950 \mathrm{~s},{ }^{1}{ }^{1}$ the differentiation and identity of the cells are governed by a nongenetic system for the regulation of gene expression termed "epigenetics". Although it has long been thought that terminally differentiated somatic cells cannot cross over the "epigenetic barrier" and transdifferentiate into other cell types, some somatic cells

*1 Division of Organogenesis and Regeneration, Medical Institute of Bioregulation, Kyushu University, Fukuoka 8128582, Japan.

$\dagger$ Correspondence should be addressed: A. Suzuki, Division of Organogenesis and Regeneration, Medical Institute of Bioregulation, Kyushu University, 3-1-1 Maidashi, Higashi-ku, Fukuoka 812-8582, Japan (e-mail: suzukicks@bioreg.kyushu-u.ac.jp). have plasticity for de- or re-differentiation, e.g., cardiomyocytes in zebrafish hearts ${ }^{2,3)}$ and pigmented epithelial cells in newt eyes. $\left.{ }^{4}\right)$ These examples suggest that terminally differentiated animal cells can convert into other cell types.

In 2006, Takahashi and Yamanaka initialized the cell fate of fibroblasts from adult mammals and re-differentiated them into various cell lineages through the forced transduction of a defined set of transcription factors.5) Their study provided information regarding the nature of cell differentiation as well as the possibility of induced pluripotent stem cell (iPSC)-based regenerative therapies. Indeed, many basic and applied studies have been performed for the realization of iPSC-based regenerative medicine. The successful application of this type of medicine has been reported, including for clinical trials of cell transplantation therapy for age-related macular degradation, ${ }^{6)}$ Parkinson's disease, ${ }^{7)}$ and corneal epithelial stem cell deficiency. ${ }^{8}$ ) At present, clinical studies of other diseases, such as spinal cord injury, severe heart failure, and stroke, are being undertaken with regards to iPSC-based regenerative medicine. Furthermore, several drug discovery studies employ- 
ing patient-derived iPSCs have identified a number of hopeful pharmaceutical candidates for treating fibrodysplasia ossificans progressiva, ${ }^{9)}$ Pendred syndrome, ${ }^{10)}$ Parkinson's disease, ${ }^{11)}$ Alzheimer's disease, ${ }^{12)}$ amyotrophic lateral sclerosis, ${ }^{13)}$ and muscular dystrophy. ${ }^{14)}$ In addition, the in vitro reconstruction of complicated and functional tissues and organs using iPSCs has also been reported, including in the brain, ${ }^{15)}$ intestines, ${ }^{16)}$ liver, ${ }^{17)}$ and kidneys. ${ }^{18)}$

Although iPSCs are a promising technology for future medicine, alternative methods for cell fate conversion, termed "direct reprogramming", have also been developed in the last decade. Direct reprogramming involves the trans-differentiation of somatic cells directly into other cell types without complete initialization. Before the first study regarding iPSCs, only a few types of direct reprogramming had been reported, including the reprogramming of fibroblasts into myoblast and pancreatic $\beta$ cells. In recent studies, various cell types have been directly converted from other somatic cell types. Most of the direct reprogramming methods applied the forced transduction of defined sets of transcription factors to convert terminally differentiated cells into specific target cells artificially. Initially, only single-transcription factor-based direct reprogramming methods were reported. ${ }^{19)-24)}$ However, most recent studies for direct reprogramming employ a combinatorial transduction strategy similar to that of the iPSC, especially in the conversion between embryologically divided cell types. Although the combinatorial expression strategy of transcription factors with viral vectors is a powerful and stable technique for direct reprogramming, alternative methods are increasing because genomic integration of the transgenes causes genomic damage, and might induce unexpected functional attenuation, abnormal proliferation, and transformation. As explained above, the major applications of the direct reprogramming technologies are bedside clinical uses, such as cell transplantation and regenerative medicine. Meanwhile, other medical, e.g., drug discovery and disease study, and nonmedical, e.g., livestock and pet industry, applications of the direct reprogramming technology have been used increasingly in recent years. Therefore, direct reprogramming technology will play a crucial role in both medical and non-medical industry.

\section{Transcription factor-based direct reprogramming technologies}

Similar to iPSC technology, most direct reprogramming methods employ forced expression of the defined set of transcription factors for cell-fate conversion (Table 1). Many are tissue-specific or developmental process-related genes; thus, it is considered that these transcription factors act as a "kickstarter" to drive the cell type-specific transcription networks. Furthermore, almost all of the

Table 1. Examples of the direct reprogramming with defined transcription factors

\begin{tabular}{|c|c|c|c|c|c|c|}
\hline Source cells & Target cells & $\begin{array}{c}\text { Transgenes and/or } \\
\text { Treatment }\end{array}$ & Species & $\begin{array}{c}\text { Cell } \\
\text { transplantation }\end{array}$ & $\begin{array}{l}\text { Published } \\
\text { year }\end{array}$ & PMID \\
\hline \multicolumn{7}{|c|}{ Neuronal (stem) cells } \\
\hline Astrocytes & $\begin{array}{l}\text { Glutamatergic } \\
\text { neurons }\end{array}$ & Pax6, Mash1, or Ngn2 & Mouse & & 2007 & $17687043^{25)}$ \\
\hline $\begin{array}{l}\text { Embryonic fibroblasts and } \\
\text { Hepatocytes }\end{array}$ & Neuronal cells & Brn2, Ascl1, and Myt1l & Mouse & & 2010,2011 & $\begin{array}{l}20107439^{26)} ; \\
21962918^{212)}\end{array}$ \\
\hline Astrocytes & $\begin{array}{l}\text { GABAergic } \\
\text { neurons }\end{array}$ & Dlx2; Dlx2 and Ascl1 & Mouse & & 2010 & $20502524^{213)}$ \\
\hline $\begin{array}{l}\text { Embryonic fibroblasts and } \\
\text { Adult skin fibroblasts }\end{array}$ & $\begin{array}{l}\text { Dopaminergic } \\
\text { neurons }\end{array}$ & Ascl1, Lmx1a, and Nurr1 & $\begin{array}{c}\text { Mouse \& } \\
\text { Human }\end{array}$ & YES & 2011 & $21725324^{27)}$ \\
\hline $\begin{array}{l}\text { Fetal fibroblasts and Post- } \\
\text { natal foreskin fibroblasts }\end{array}$ & Neuronal cells & $\begin{array}{l}\text { BRN2, ASCL1, MYT1L, } \\
\text { and NEUROD1 }\end{array}$ & Human & & 2011 & $21617644^{28)}$ \\
\hline $\begin{array}{l}\text { Embryonic fibroblasts and } \\
\text { Postnatal fibroblasts }\end{array}$ & Neuronal cells & $\begin{array}{l}\text { ASCL1, BRN2, MYT1L, } \\
\text { LMX1A, and FOXA2 }\end{array}$ & Human & & 2011 & $21646515^{29)}$ \\
\hline Embryonic fibroblasts & Neural stem cells & $\begin{array}{l}\text { Brn4/Pou3f4, Sox } 2, \text { Klf4, } \\
\text { c-Myc, and E47/Tcf3 }\end{array}$ & Mouse & YES & 2012 & $22445517^{30)}$ \\
\hline
\end{tabular}


Continued.

\begin{tabular}{|c|c|c|c|c|c|c|}
\hline $\begin{array}{l}\text { Embryonic fibroblasts and } \\
\text { Fetal foreskin fibroblasts }\end{array}$ & Neural stem cells & Sox 2 & $\begin{array}{c}\text { Mouse \& } \\
\text { Human }\end{array}$ & YES & 2012 & $22683203^{31)}$ \\
\hline Sertoli cells & Neural stem cells & $\begin{array}{l}\text { Pax6, Ngn2, Hes1, Id1, } \\
\text { Ascl1, Brn2, c-Myc, and } \\
\text { Klf4 }\end{array}$ & Mouse & YES & 2012 & $22064700^{32)}$ \\
\hline Fibroblasts (IMR90 cells) & $\begin{array}{l}\text { Dopaminergic } \\
\text { neurons }\end{array}$ & $\begin{array}{l}\text { MASH1, NGN2, SOX2, } \\
\text { NURR1, and PITX3 + A } \\
\text { dominant-negative P53 }\end{array}$ & Human & YES & 2014 & $25129808^{214)}$ \\
\hline $\begin{array}{l}\text { Non-sensory cochlear } \\
\text { epithelial cells }\end{array}$ & Neuronal cells & Ascl1; Ascl1 and Neurod & Mouse & & 2014 & $24928351^{39)}$ \\
\hline Astrocytes & Neuronal cells & Brn4 & Mouse & & 2014 & $24887289^{185)}$ \\
\hline Skin fibroblasts & $\begin{array}{l}\text { Dopaminergic } \\
\text { precursors }\end{array}$ & Brn2, Sox2, and Foxa2 & Mouse & YES & 2015 & $26224135^{215)}$ \\
\hline Adult skin fibroblasts & Motor neurons & $\begin{array}{l}\text { NEUROG2, SOX11, ISL1, } \\
\text { and LHX3 }\end{array}$ & Human & & 2016 & $26725112^{46)}$ \\
\hline Fibroblasts (3T6 cells) & Neuronal cells & Ascl1, Brn4, and Tcf3 & Mouse & & 2017 & $29137640^{216)}$ \\
\hline Umbilical cord blood cells & Neural stem cells & SOX2 and HMGA2 & Human & & 2017 & $28844127^{33)}$ \\
\hline Fibroblasts (3T6 cells) & Neuronal cells & Ascl1, Brn2, and Foxa1 & Mouse & & 2017 & $28855426^{119)}$ \\
\hline Resident glial cells & Neuronal cells & Ascl1, Lmx1a, and Nurr1 & Mouse & & 2017 & $28844658^{41)}$ \\
\hline $\begin{array}{l}\text { Fibroblast-like cells from } \\
\text { retinal tissues }\end{array}$ & Neuronal cells & ASCL1 and PAX6 & Human & & 2017 & $28697461^{217)}$ \\
\hline $\begin{array}{l}\text { Pluripotent stem cell- } \\
\text { derived cardiomyocytes }\end{array}$ & Neuronal cells & $\begin{array}{l}\text { Brn2, Ascl1, Myt1l and } \\
\text { Neurod }\end{array}$ & $\begin{array}{c}\text { Mouse \& } \\
\text { Human }\end{array}$ & & 2017 & $28327614^{218)}$ \\
\hline Fibroblasts & Motor neurons & $\begin{array}{l}\text { ASCL1, ISL1, } \\
\text { NEUROD1, BRN2, HB9, } \\
\text { LHX3, MYT1L, and } \\
\text { NGN2 }\end{array}$ & Human & & 2017 & $28099929^{219)}$ \\
\hline Fibroblasts & Neurocytes & $\begin{array}{l}\text { SOX2, GATA3, and } \\
\text { NEUROD1 }\end{array}$ & Human & & 2017 & $28587331^{62)}$ \\
\hline Dermal fibroblasts & $\begin{array}{l}\text { Neural precursor } \\
\text { cells }\end{array}$ & SOX2 and PAX6 & Human & & 2018 & $30450440^{34)}$ \\
\hline $\begin{array}{l}\text { Embryonic fibroblasts and } \\
\text { Newborn foreskin fibro- } \\
\text { blasts }\end{array}$ & Neural stem cells & Ptfla & $\begin{array}{c}\text { Mouse \& } \\
\text { Human }\end{array}$ & YES & 2018 & $30030434^{35)}$ \\
\hline Adult fibroblasts & $\begin{array}{l}\text { Neural precursor } \\
\text { cells }\end{array}$ & $\begin{array}{l}\text { SOX2; SOX2 and PAX6; } \\
\text { SOX2 and LMX1A; } \\
\text { SOX2, LMX1A, and } \\
\text { FOXA2 }\end{array}$ & Human & & 2018 & $30018471^{36)}$ \\
\hline $\begin{array}{l}\text { Spiral ganglion non- } \\
\text { neuronal cells } \\
\end{array}$ & Neuronal cells & Ascl1 and Neurod & Mouse & & 2018 & $29492404^{220)}$ \\
\hline $\begin{array}{l}\text { Umbilical cord mesenchy- } \\
\text { mal stem cells }\end{array}$ & Neuronal cells & $\begin{array}{l}\text { SOX2, ASCL1, and } \\
\text { NEUROG2 }\end{array}$ & Human & & 2018 & $29937717^{221)}$ \\
\hline Pericytes & Neuronal cells & ASCL1 and SOX2 & Human & & 2018 & $29915193^{181)}$ \\
\hline Cord blood CD133(+) cells & Neuronal cells & $\begin{array}{l}\text { FOXM1, SOX2, MYC, } \\
\text { SALL4, and STAT6 }\end{array}$ & Human & & 2018 & $29653196^{38)}$ \\
\hline
\end{tabular}


Continued.

\begin{tabular}{|c|c|c|c|c|c|c|}
\hline Hepatocytes & Neuronal cells & $\begin{array}{l}\text { Suz12, Ezh2, Meis1, Sry, } \\
\text { Smarca4, Esr1, Pparg, and } \\
\text { Stat3 }\end{array}$ & Mouse & & 2018 & $29653196^{38)}$ \\
\hline Peripheral CD34 $(+)$ cells & Neural stem cells & $\begin{array}{l}\text { AR, SOX2, SMAD3, } \\
\text { MYC, JUN, WT1, TAL1, } \\
\text { SPI1, and RUNX1 }\end{array}$ & Human & & 2018 & $29653196^{38)}$ \\
\hline Urine epithelial-like cells & Neural stem cells & $\begin{array}{l}\text { POU3F2, SOX2, BACH1, } \\
\text { AR, PBX1, and NANOG }\end{array}$ & Human & & 2018 & $29653196^{38)}$ \\
\hline Muller glia cells & Neural stem cells & $\begin{array}{l}\text { Bmi1, Spi1, Lmo2, and } \\
\text { Cebpd }\end{array}$ & Mouse & & 2018 & $29653196^{38)}$ \\
\hline $\begin{array}{l}\text { Astrocytes and Foreskin } \\
\text { fibroblasts }\end{array}$ & $\begin{array}{l}\text { Noradrenergic } \\
\text { neurons }\end{array}$ & $\begin{array}{l}\text { Ascl1, Phox2b, Ap-2a, } \\
\text { Gata3, Hand2, Nurr1, and } \\
\text { Phox2a }\end{array}$ & $\begin{array}{l}\text { Mouse \& } \\
\text { Human }\end{array}$ & YES & 2019 & $31315047^{222)}$ \\
\hline $\begin{array}{l}\text { Bone marrow-derived cells, } \\
\text { Fibroblasts, and Keratino- } \\
\text { cytes }\end{array}$ & $\begin{array}{l}\text { Neural precursor } \\
\text { cells }\end{array}$ & MSI1, NGN2, and MBD2 & Human & YES & 2019 & $31196173^{37)}$ \\
\hline Microglial cells & Neuronal cells & Neurod1 & Mouse & & 2019 & $30638745^{44)}$ \\
\hline \multicolumn{7}{|c|}{ Cardiomyocytes } \\
\hline Cardiac fibroblasts & Cardiomyocytes & Gata4, Mef2c, and Tbx5 & Mouse & YES & 2010 & $20691899^{49)}$ \\
\hline Cardiac fibroblasts & Cardiomyocytes & $\begin{array}{l}\text { Gata } 4 \text {, Mef2c, Tbx } 5 \text {, and } \\
\text { Hand } 2\end{array}$ & Mouse & & 2012 & $22660318^{50)}$ \\
\hline $\begin{array}{l}\text { Cardiac fibroblasts and } \\
\text { Embryonic fibroblasts }\end{array}$ & Cardiomyocytes & $\begin{array}{l}\text { Mef2c and Tbx } 5+\text { Myocd } \\
\text { or Gata } 4\end{array}$ & Mouse & & 2012 & $22575762^{51)}$ \\
\hline Cardiac fibroblasts & Cardiomyocytes & $\begin{array}{l}\text { GATA4, MEF } 2 \text { C, TBX5, } \\
\text { MESP1, and MYOCD }\end{array}$ & Human & & 2013 & $23861494^{52)}$ \\
\hline $\begin{array}{l}\text { Embryonic stem cells- } \\
\text { derived fibroblasts }\end{array}$ & Cardiomyocytes & $\begin{array}{l}\text { GATA4, MEF2C, TBX5, } \\
\text { ESRRG, MESP1, ZFPM2, } \\
\text { and MYOCD }\end{array}$ & Human & YES & 2013 & $24319660^{53)}$ \\
\hline $\begin{array}{l}\text { Adult tail-tip fibroblasts } \\
\text { and Cardiac fibroblasts }\end{array}$ & Cardiomyocytes & $\begin{array}{l}\text { Mef2c and Tbx5 + Bmi1 } \\
\text { knockdown }\end{array}$ & Mouse & & 2016 & $26942853^{175)}$ \\
\hline Adult fibroblasts & Cardiomyocytes & $\begin{array}{l}\text { Gata4, Hand2, Mef2c, } \\
\text { Tbx5, and Znf281 }\end{array}$ & Mouse & & 2017 & $28982760^{167)}$ \\
\hline \multicolumn{7}{|c|}{ Hepatocytes } \\
\hline $\begin{array}{l}\text { Embryonic fibroblasts and } \\
\text { Adult dermal fibroblasts }\end{array}$ & Hepatocytes & $\begin{array}{l}\text { Hnf4a and Foxa1, Foxa2, } \\
\text { or Foxa3 }\end{array}$ & Mouse & YES & 2011 & $21716291^{55)}$ \\
\hline Caudal fibroblasts & Hepatocytes & $\begin{array}{l}\text { Gata4, Hnf1a, and } \\
\text { Foxa3 }+ \text { p19 } \\
\text { knockdown }\end{array}$ & Mouse & YES & 2011 & $21562492^{56)}$ \\
\hline Embryonic fibroblasts & Hepatocytes & $\begin{array}{l}\text { HNF1A, HNF4A, HNF6, } \\
\text { ATF5, PROX1, CEBPA, } \\
\text { and MYC + TP53 } \\
\text { knockdown }\end{array}$ & Human & YES & 2014 & $24582926^{57)}$ \\
\hline $\begin{array}{l}\text { Fetal and adult fibroblasts } \\
\text { and Adipose tissue-derived } \\
\text { mesenchymal stem cells }\end{array}$ & Hepatocytes & $\begin{array}{l}\text { FOXA3, HNF1A, and } \\
\text { HNF4A + SV40 large T } \\
\text { antigen }\end{array}$ & Human & YES & 2014 & $24582927^{58)}$ \\
\hline
\end{tabular}


Continued.

\begin{tabular}{|c|c|c|c|c|c|c|}
\hline $\begin{array}{l}\text { Fibroblasts (BJ and MRC-5 } \\
\text { cells) }\end{array}$ & Hepatocytes & $\begin{array}{l}\text { HNF1A and Any two of } \\
\text { the three factors: FOXA1, } \\
\text { FOXA3, and HNF4A }\end{array}$ & Human & & 2014 & $24963715^{59)}$ \\
\hline $\begin{array}{l}\text { Liver cells in mouse models } \\
\text { of chronic liver disease }\end{array}$ & Hepatocytes & $\begin{array}{l}\text { Foxa3, Gata4, Hnf1a, and } \\
\text { Hnf4a }\end{array}$ & Mouse & & 2016 & $26923201^{60)}$ \\
\hline Fetal lung fibroblasts & Hepatocytes & $\begin{array}{l}\text { ATF5, PROX1, FOXA2, } \\
\text { FOXA3, and HNF4A }\end{array}$ & Human & & 2017 & $29192290^{61)}$ \\
\hline Fibroblasts & Hepatocytes & $\begin{array}{l}\text { OCT4, FOXA2, HNF1A, } \\
\text { and GATA3 }\end{array}$ & Human & & 2017 & $28587331^{62)}$ \\
\hline Embryonic fibroblasts & Hepatocytes & Foxa3, Hnf1a, and Gata4 & Mouse & YES & 2018 & $29959867^{63)}$ \\
\hline Embryonic fibroblasts & Hepatocytes & $\begin{array}{l}\text { Hnf4a, Foxa3, Klf4, and } \\
\text { c-Myc }\end{array}$ & Mouse & YES & 2019 & $30635054^{64)}$ \\
\hline \multicolumn{7}{|c|}{ Islet-related cells } \\
\hline Liver cells in vivo & $\beta$ cells & Pdx1 & Mouse & & 2000,2003 & $\begin{array}{l}10802714^{20)} \\
12775714^{21)}\end{array}$ \\
\hline $\begin{array}{l}\text { Pancreatic exocrine cells } \\
\text { in vivo }\end{array}$ & $\beta$ cells & Ngn3, Pdx1, and Mafa & Mouse & & 2008 & $18754011^{65)}$ \\
\hline Hepatocytes & Islet cells & Ngn3 & Mouse & & 2009 & $19793886^{24)}$ \\
\hline Liver cells & $\beta$ cells & $\begin{array}{l}\text { PDX1, PAX4, and } \\
\text { MAFA }\end{array}$ & Human & & 2014 & $24504462^{66)}$ \\
\hline $\begin{array}{l}\text { Cultured adult pancreatic } \\
\text { duct cells }\end{array}$ & $\beta$ cells & Pdx1, Ngn3, and Mafa & Mouse & & 2015 & $25836667^{67)}$ \\
\hline Gallbladder cells & $\beta$ cells & $\begin{array}{l}\text { Pdx1, Ngn, Mafa, and } \\
\text { Pax6 }\end{array}$ & Mouse & YES & 2016 & $27833043^{68)}$ \\
\hline \multicolumn{7}{|c|}{ Hematopoietic system-related cells } \\
\hline $\mathrm{T}$ precursor cells & Macrophages & Cebpa or Cebpb & Mouse & & 2006 & $17088084^{22)}$ \\
\hline $\mathrm{T}$ precursor cells & Dendritic cells & Pu.1 & Mouse & & 2006 & $17088084^{22)}$ \\
\hline $\mathrm{B}$ cells & $\mathrm{T}$ cells & Pax5 knockout & Mouse & YES & 2007 & $17851532^{73)}$ \\
\hline $\begin{array}{l}\text { Fibroblasts ( } 3 \mathrm{~T} 3 \text { cells), } \\
\text { Embryonic fibroblasts, and } \\
\text { Adult skin fibroblasts }\end{array}$ & $\begin{array}{l}\text { Macrophage-like } \\
\text { cells }\end{array}$ & Pu.1 and Cebpa or Cebpb & Mouse & & 2008 & $18424555^{74)}$ \\
\hline $\mathrm{B}$ cells & Erythroid cells & Gata1, Scl, and Cebpa & Mouse & & 2012 & $22968040^{223)}$ \\
\hline $\begin{array}{l}\text { Fibroblasts (3T3 cells) and } \\
\text { Adult dermal fibroblasts }\end{array}$ & Megakaryocyte & Nfe2, Mafg, and Mafk & $\begin{array}{c}\text { Mouse \& } \\
\text { Human }\end{array}$ & YES & 2012 & $22855609^{75)}$ \\
\hline Skin fibroblasts & Monocytes & $\begin{array}{l}\text { Spl1, Cebpa, Mnda, and } \\
\text { Irf8 }\end{array}$ & Mouse & & 2012 & $22428058^{76)}$ \\
\hline $\begin{array}{l}\text { Embryonic fibroblasts and } \\
\text { Adult ear skin fibroblasts }\end{array}$ & $\begin{array}{l}\text { Hematopoietic } \\
\text { progenitor cells }\end{array}$ & $\begin{array}{l}\text { Erg, Gata2, Lmo2, } \\
\text { Runx1c, and Scl }\end{array}$ & Mouse & YES & 2014 & $25466247^{77)}$ \\
\hline Fibroblasts & $\begin{array}{l}\text { Antigen-present- } \\
\text { ing dendritic cells }\end{array}$ & Pu.1, Irf8, and Batf3 & $\begin{array}{c}\text { Mouse \& } \\
\text { Human }\end{array}$ & & 2018 & $30530727^{78)}$ \\
\hline \multicolumn{7}{|c|}{ Bone-related cells } \\
\hline $\begin{array}{l}\text { Neonatal foreskin fibro- } \\
\text { blasts }\end{array}$ & $\begin{array}{l}\text { Chondrogenic } \\
\text { cells }\end{array}$ & c-MYC, KLF4, and SOX9 & Human & YES & 2013 & $24146984^{224)}$ \\
\hline
\end{tabular}


Continued.

\begin{tabular}{|c|c|c|c|c|c|c|}
\hline Dermal fibroblasts & Osteoblasts & $\begin{array}{l}\text { OCT } 3 / 4 \text { and OCT } 6 \text { or } \\
\text { OCT } 9+\mathrm{L}-\mathrm{MYC} \text {, } \\
\text { c-MYC, or N-MYC }\end{array}$ & Human & & 2015 & $26499074^{79)}$ \\
\hline Fibroblasts & Osteoblasts & $\begin{array}{l}\text { RUNX2, OCT4, } \\
\text { OSTERIX, and L-MYC }\end{array}$ & Human & YES & 2015 & $25918395^{80)}$ \\
\hline $\begin{array}{l}\text { Gingival fibroblasts and } \\
\text { Adult dermal fibroblasts }\end{array}$ & Osteoblasts & $\begin{array}{l}\text { OCT4, OSTERIX, and } \\
\text { L-MYC }\end{array}$ & Human & YES & 2016 & $26990860^{81)}$ \\
\hline Embryonic fibroblasts & Osteoblasts & c-Myc, Oct4, and hLMP3 & Mouse & YES & 2019 & $30453092^{82)}$ \\
\hline \multicolumn{7}{|c|}{ Skeletal muscle-related cells } \\
\hline $\begin{array}{l}\text { Fibroblasts (C3H10T1/2 } \\
\text { cells) }\end{array}$ & Myoblasts & Myod & Mouse & & 1987 & $3690668^{19)}$ \\
\hline Dermal fibroblasts & Myoblasts & MYOD1 and MYCL & Human & YES & 2017 & $28501623^{83)}$ \\
\hline Embryonic fibroblasts & $\begin{array}{l}\text { Skeletal muscle } \\
\text { progenitor cells }\end{array}$ & $\begin{array}{l}\text { Mef } 2 \mathrm{~b} \text { and Pitx1 + Pax } 3 \\
\text { or Pax7 }\end{array}$ & Mouse & YES & 2018 & $28808339^{84)}$ \\
\hline Adult fibroblasts & $\begin{array}{l}\text { Skeletal muscle } \\
\text { progenitor cells }\end{array}$ & Pax7, Mef2b, and Myod & Mouse & YES & 2018 & $28808339^{84)}$ \\
\hline \multicolumn{7}{|c|}{ Other cells } \\
\hline $\begin{array}{l}\text { Embryonic fibroblasts and } \\
\text { Newborn foreskin fibro- } \\
\text { blasts }\end{array}$ & Brown fat cells & Prdm16 and Cebpb & $\begin{array}{c}\text { Mouse \& } \\
\text { Human }\end{array}$ & YES & 2009 & $19641492^{95)}$ \\
\hline Embryonic fibroblasts & Sertoli cells & $\begin{array}{l}\text { Nr5a1, Wt1, Dmrt1, } \\
\text { Gata4, and Sox9 }\end{array}$ & Mouse & YES & 2012 & $22958931^{96)}$ \\
\hline Iris-derived cells & $\begin{array}{l}\text { Photoreceptor } \\
\text { cells }\end{array}$ & $\begin{array}{l}\text { CRX, RAX, and } \\
\text { NEUROD }\end{array}$ & Human & & 2012 & $22558175^{85)}$ \\
\hline $\begin{array}{l}\text { Embryonic fibroblasts and } \\
\text { Adult tail-tip dermal fibro- } \\
\text { blasts }\end{array}$ & Melanocytes & Mitf, Sox10, and Pax3 & $\begin{array}{c}\text { Mouse \& } \\
\text { Human }\end{array}$ & YES & 2014 & $25510211^{97)}$ \\
\hline $\begin{array}{l}\text { Adipose tissue-derived } \\
\text { stromal cells }\end{array}$ & Endothelial cells & SOX18 & Human & & 2014 & $25290189^{93)}$ \\
\hline Dermal fibroblasts & $\begin{array}{l}\text { Photoreceptor } \\
\text { cells }\end{array}$ & $\begin{array}{l}\text { CRX, RAX, OTX2, and } \\
\text { NEUROD }\end{array}$ & Human & & 2014 & $24456169^{86)}$ \\
\hline Embryonic fibroblasts & $\begin{array}{l}\text { Thymic epithelial } \\
\text { cells }\end{array}$ & Foxn1 & Mouse & YES & 2014 & $25150981^{98)}$ \\
\hline Fibroblasts & Sweat gland cells & $\mathrm{NF}-\kappa \mathrm{B}$ and LEF-1 & Human & YES & 2015 & $26566868^{91)}$ \\
\hline Amniotic fluid stem cells & $\begin{array}{l}\text { Pluripotent stem } \\
\text { cells }\end{array}$ & OCT4 & Human & & 2016 & $27019637^{225)}$ \\
\hline $\begin{array}{l}\text { Cardiac mesenchymal pro- } \\
\text { genitors }\end{array}$ & Adipocytes & Klf4 and c-Myc & Mouse & & 2016 & $27077806^{87)}$ \\
\hline $\begin{array}{l}\text { Embryonic fibroblasts, } \\
\text { Adult tail-tip dermal fibro- } \\
\text { blasts, Postnatal foreskin } \\
\text { fibroblasts, and Fetal } \\
\text { dermal fibroblasts }\end{array}$ & $\begin{array}{l}\text { Renal tubular } \\
\text { epithelial cells }\end{array}$ & $\begin{array}{l}\text { Emx2, Hnf1b, Hnf4a, and } \\
\text { Pax8 }\end{array}$ & $\begin{array}{l}\text { Mouse \& } \\
\text { Human }\end{array}$ & YES & 2016 & $27820600^{99)}$ \\
\hline Endothelial progenitor cells & $\begin{array}{l}\text { Smooth muscle } \\
\text { cells }\end{array}$ & MYOCD & Human & & 2016 & $26874281^{89)}$ \\
\hline
\end{tabular}


Continued.

\begin{tabular}{|c|c|c|c|c|c|c|}
\hline Embryonic stem cells & $\begin{array}{l}\text { Trophoblast stem } \\
\text { cells }\end{array}$ & Cdx2, Arid3a, and Gata3 & Mouse & & 2017 & $28973471^{102)}$ \\
\hline $\begin{array}{l}\text { Embryonic fibroblasts and } \\
\text { Adult tail-tip dermal fibro- } \\
\text { blasts }\end{array}$ & Leydig cells & Dmrt1, Gata4, and Nr5a1 & Mouse & YES & 2017 & $28017657^{101)}$ \\
\hline $\begin{array}{l}\text { Postnatal dermal fibro- } \\
\text { blasts }\end{array}$ & Endothelial cells & $\begin{array}{l}\text { ER71/ETV2 (ETS } \\
\text { variant 2) }\end{array}$ & Human & YES & 2017 & $28003219^{94)}$ \\
\hline Dermal fibroblasts & Adipocytes & PPARG2 & Human & & 2017 & $28982679^{88)}$ \\
\hline $\begin{array}{l}\text { Embryonic fibroblasts and } \\
\text { Umbilical vein endothelial } \\
\text { cells }\end{array}$ & $\begin{array}{l}\text { Intestine progeni- } \\
\text { tor cells }\end{array}$ & $\begin{array}{l}\text { Hnf4a, Foxa3, Gata6, and } \\
\text { Cdx2 }\end{array}$ & $\begin{array}{c}\text { Mouse \& } \\
\text { Human }\end{array}$ & YES & 2017 & $28943029^{100)}$ \\
\hline $\begin{array}{l}\text { Embryonic fibroblasts and } \\
\text { Adult dermal fibroblasts }\end{array}$ & $\begin{array}{l}\text { Smooth muscle } \\
\text { cells }\end{array}$ & Myocd, Gata6, and Mef2c & $\begin{array}{c}\text { Mouse \& } \\
\text { Human }\end{array}$ & & 2018 & $30026272^{90)}$ \\
\hline Epidermal cells & Sweat gland cells & Foxc1 & Mouse & YES & 2019 & $30894517^{92)}$ \\
\hline $\begin{array}{l}\text { Renal proximal tubular } \\
\text { epithelial (HK2) cells }\end{array}$ & $\begin{array}{l}\text { Nephron progeni- } \\
\text { tor cells }\end{array}$ & SNAI2, EYA1, and SIX1 & Human & & 2019 & $30827514^{103)}$ \\
\hline
\end{tabular}

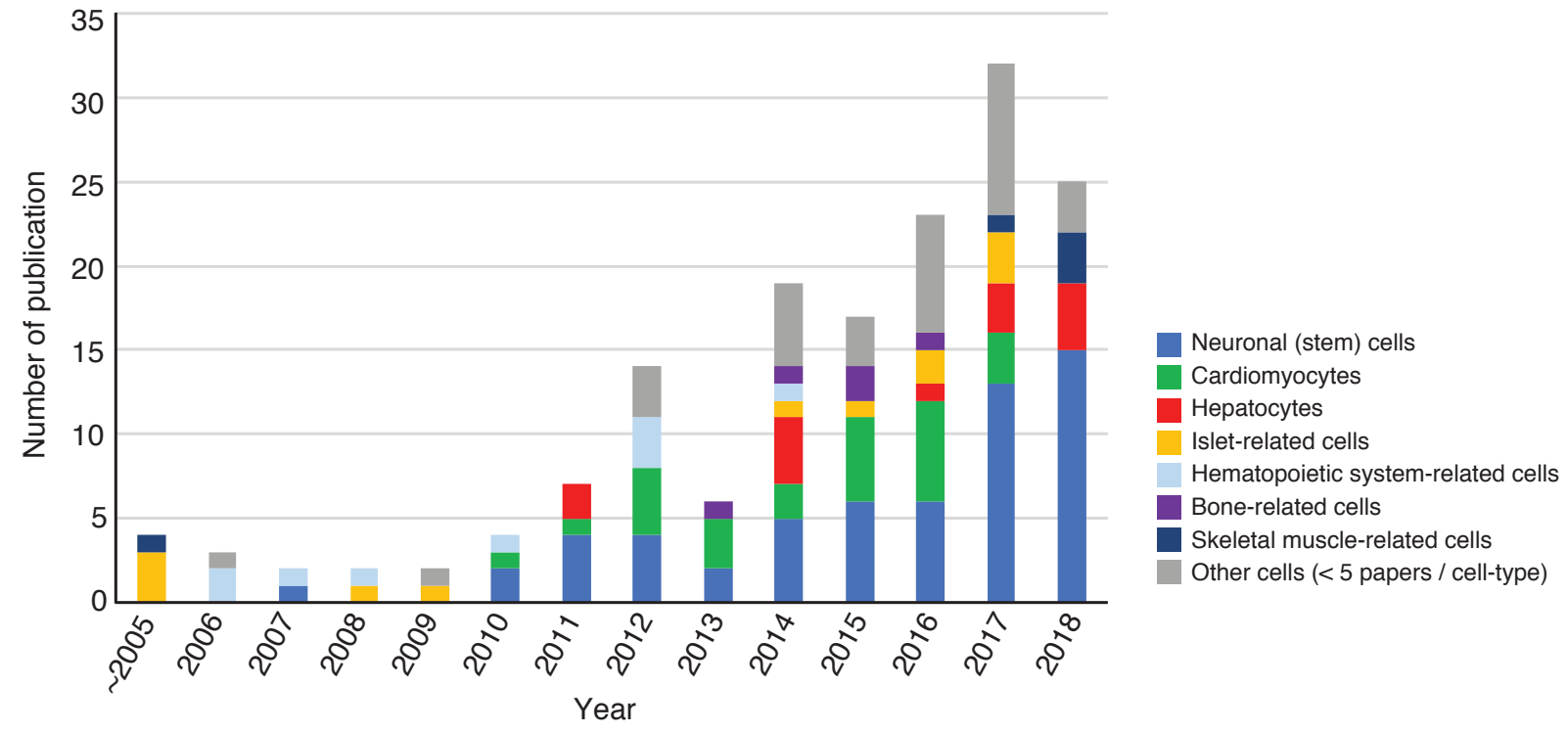

Fig. 1. The number of publications relating to direct reprogramming studies. The publications relating to direct reprogramming studies of different target cell types are shown as a bar chart. Each different color refers to an individual target cell type. In order to survey the direct reprogramming studies published previously, original articles were searched on PubMed with the following search formula: "direct reprogramming" [All Fields].

reprogramming factor gene sets contain at least one pioneer factor, which is a transcription factor capable of opening closed chromatin sections. These factors may play a pivotal role in the machinery of direct reprogramming. In this section, examples and applications for various types of transcription factor-based direct reprogramming are introduced.
2.1. Neuronal cells. By the end of 2018, the most reported target cells for direct reprogramming were neuronal lineage cells, including neural stem/ progenitor cells (Fig. 1). The first example of the direct lineage conversion to neuronal cells was the reprogramming of astrocytes toward glutamatergic neurons with the transduction of single transcription 
factors in vitro: Pax6, Mash1, or Ngn2. ${ }^{25)}$ However, the presynaptic output function of the astrocytederived neurons was insufficient, and the conversion was only achieved between closely related cells. In 2010, more successfully reprogrammed neuronal cells, termed induced neuronal (iN) cells, were reported. Combinatorial transduction of a set of transcription factors, Brn2, Ascl1, and Myt1l, induced functional neuron-like cells from mouse embryonic fibroblasts (MEFs) and hepatocytes in vitro. ${ }^{26)}$ One year later, some studies generated iN cells from human fibroblasts. ${ }^{27)-29)}$ Although the combination and member of the transcription factors in each study were different, only one transcription factor, Ascl1, was employed in almost every iN cell conversion method. This indicated that Ascl1 may be a vital regulator of neuronal reprogramming but can also be compensated for by other related factors. In addition to terminally differentiated neuronal cells, the direct induction of neural stem/progenitor cells, which are expandable and differentiate to a wide variety of neuronal lineage cells, was also reported. ${ }^{30)-37)}$ The combinations of transcription factors for the induction of neural stem/progenitor cells were significantly different from those of the differentiated iN cells; thus, this might indicate that the transcription networks in the differentiated neuronal cells and the neural stem/progenitor cells are significantly different. In recent years, studies on the generation of multipotent neural stem/progenitor cells have increased because these cells can proliferate in vitro for use in cell transplantation therapies. ${ }^{30-38)}$ On the other hand, in vivo direct reprogramming studies for terminally differentiated iN cells are also increasing. In these studies, endogenous cells in the brain, such as glial cells, are converted into functional neuronlike cells in situ with plasmid transfection or viral vector infection. ${ }^{39)-44)}$ Furthermore, iN cells have been applied for non-therapeutic applications; for example, direct neuronal reprogramming of cells from patients with severe nerve diseases, such as Huntington's disease, amyotrophic lateral sclerosis, and myoclonus epilepsy associated with ragged red fibers, have been developed for pathological analysis and drug discovery studies. ${ }^{45)}{ }^{48)}$

2.2. Cardiomyocytes. Cardiomyocytes, striated muscle cells in the heart, are the second most frequently reported target cells in the field of direct reprogramming (Fig. 1). Cardiomyocytes are one of the most desirable cells for establishment in regenerative medicine because they are not expandable in vivo or in vitro. The first study of mouse-induced cardiomyocyte-like (iCM) cells was published in $2010,{ }^{49)}$ which was followed by other studies using different combinations of transcription factors. ${ }^{50), 51)}$ Human fibroblast-derived iCM cells were established in 2013. ${ }^{52), 53)}$ As well as iN cells, the combination of transcription factors for iCM cells shows wide variation, which might indicate redundancy of the transcription network of cardiomyocytes. However, only Tbx5 was included in all of the combinations of transcription factors for iCM cells. Therefore, it is considered that Tbx5 plays a central role in the transcription network of cardiomyocytes, similar to Ascl1 in neuronal cells. In previous studies, fibroblasts have frequently been employed as source cells for iCM cells because cardiac fibroblasts, which exist abundantly in the heart, are considered a potential candidate for source cells of in situ direct reprogramming. Some studies have achieved successful in vivo direct reprogramming of iCM cells in mouse hearts by using lentivirus vectors. ${ }^{50), 54)}$ This technology may benefit patients with heart injury, such as myocardial infarction.

2.3. Hepatocytes. Hepatocytes are parenchymal cells of the liver and have vital roles in this organ, i.e., lipid metabolism, glycogen accumulation, detoxification, and endocrine activities. As well as neuronal cells and cardiomyocytes, hepatocytes are also expected to be induced artificially for therapeutic uses because the specific functions of liver-derived hepatocytes cannot be maintained in canonical in vitro culture conditions and are unsuitable for cell transplantation therapy. Although iPSC-derived hepatocytes have been actively studied, the direct reprogramming of hepatocytes is also considered a promising alternative for regenerative treatments of the liver. The first studies of mouse-induced hepatocyte-like (iHep) cells were published by two independent groups simultaneously. ${ }^{55), 56)}$ Although these studies used different protocols to induce iHep cells from fibroblasts, the resulting iHep cells showed similar phenotypes to those of endogenous hepatocytes, i.e., secretion of albumin, uptake of lowdensity lipoprotein, and xenobiotic metabolism. Furthermore, studies were also conducted using human and mouse iHep cells in a wide variety of reprogramming factor combinations. ${ }^{55)-64)}$ The transcription network defining the cell fate of hepatocytes appears complex and may have redundancy. Among the transcription factors for iHep cell conversion, the Foxa family of transcription factors, i.e., Foxa1, Foxa2, and Foxa3, are considered primary factors for hepatic reprogramming because almost all iHep cell 
induction methods employ this family proteins as well as Ascl1 and Tbx5 in other direct reprogramming methods. iHep cells are expected to have potential in cell transplantation therapies because the induced cells are expandable and maintain their hepatic functions, unlike the liver-derived hepatocytes. Nevertheless, the human iHep cells required unfavorable factors, such as a virus-derived gene, to be expandable cells; therefore, further improvements are necessary for the medical use of iHep cells. In vivo reprogramming of the iHep cells with an adenoassociated virus (AAV) vector is also studied to treat liver disorders, such as cirrhosis, ${ }^{60)}$ because the fibrous liver contains a massive number of fibroblasts as source cells for the direct reprogramming and exclusion target cells.

2.4. Islet-related cells. Among the five types of endocrine cells in pancreatic islets, $\beta$ cells are the most critical targets for regenerative medicine because they are the unique source of insulin and are destroyed in type 1 diabetes. Of note, all of the cells reported to be reprogrammed into $\beta$ cells were endoderm-derived cells, e.g., hepatocytes, bile duct cells, pancreatic exocrine cells, and gallbladder cells, without exception. ${ }^{20), 21), 24), 65)-71)}$ The fact that only cells of closely related lineages have been converted into $\beta$ cells might indicate the peculiarity of $\beta$ cells from other lineages and plasticity among endodermderived cells. Relatively large numbers of studies of the in vivo direct reprogramming of these cells have been reported, because the generation of insulinsecreting cells in digestive organs is an easy and effective solution for type 1 diabetes.

2.5. Hematopoietic system-related cells. Several terminally differentiated blood cells, e.g., dendritic cells, macrophages, and T cells, were easily converted from other blood cells by transducing with single transcription factors. ${ }^{72), 73)}$ Therefore, these studies were reported earlier the other direct reprogramming studies. On the other hand, the direct reprogramming of blood cells from fibroblasts requires much more complex sets of transcription factors. ${ }^{74)}$-78) The long-distance lineage conversion appears to require a larger number of transcription factors than the short-distance lineage conversion to drastically change their transcription network. Toward practical use, the in vitro conversion of various types of blood cells has been studied vigorously to prepare cells for blood component transfusion.

2.6. Other types of cells. Since the first report of the direct reprogramming of somatic cells into myoblasts in $1987,{ }^{19)}$ a vast number of different direct reprogramming techniques have been reported; for example, osteoblasts, ${ }^{79)-82)}$ myoblasts, ${ }^{19), 83)}$ skeletal muscle progenitor cells, ${ }^{84}$ photoreceptor cells, ${ }^{85), 86)}$ adipocytes, ${ }^{87), 88)}$ smooth muscle cells, ${ }^{89), 90)}$ sweat gland cells, ${ }^{91), 92)}$ and endothelial cells ${ }^{93,94)}$ have been induced with several combinations of transcription factors. In addition, the direct conversion of various types of cells, such as brown fat cells, ${ }^{95)}$ Sertoli cells,${ }^{96)}$ melanocytes, ${ }^{97)}$ thymic epithelial cells,$\left.{ }^{98}\right)$ renal tubular epithelial cells, ${ }^{99)}$ intestine progenitor cells, ${ }^{100)}$ Leydig cells, ${ }^{101)}$ trophoblast stem cells, ${ }^{102}$ ) and nephron progenitor cells, ${ }^{103)}$ has been achieved successfully, and this method is expected to be applied in medical treatment, drug discovery, and pathological studies. Indeed, the researchers of some studies employed the directly reprogrammed cells from patient-derived somatic cells for their disease research. ${ }^{88), 104), 105)}$

2.7. Prediction of the combinations of transcription factors. Although most direct reprogramming studies select transcription factor combinations from factor lists developed in previous studies in genetics, genomics, and developmental biology, this type of screening is unreliable and inefficient. Therefore, several tools for the prediction of reprogramming factors have been developed. For these studies, a large amount of comprehensive biological data, e.g., transcriptome and topologically associating domains, with computer algorithms, e.g., machine learning and network analysis, were employed to develop the prediction model. ${ }^{106)-110)}$ These tools made the selection of transcription factor candidates and combinations easier. Therefore, the number and variation of direct reprogramming techniques using transcription factors will continue to increase.

\section{Methods for direct cell fate conversion}

Although the majority of direct reprogramming has been achieved through the forced transduction of transcription factors with viral vectors, these methods are expected to be replaced with alternative methods (Table 2). This is because frequently used viral vectors, retroviruses, and lentivirus vectors integrate the transgenes into the host genome and increase the risk of unexpected cell proliferation, transformation, and oncogenesis. Furthermore, although integration-free transduction methods, e.g., adenovirus vectors, AAV vectors, and plasmid vectors, are employed, the possibility of accidental genome integration of foreign DNA remains. Therefore, integration-free, DNA-free, and transgene-free methods are desired for medical applications. In this 
Table 2. Examples of the direct reprogramming with various methods

\begin{tabular}{|c|c|c|c|c|c|c|}
\hline Source cells & Target cells & $\begin{array}{c}\text { Transgenes and/or } \\
\text { Treatment }\end{array}$ & Species & $\begin{array}{c}\text { Cell } \\
\text { transplantation }\end{array}$ & $\begin{array}{l}\text { Published } \\
\text { year }\end{array}$ & PMID \\
\hline \multicolumn{7}{|c|}{ Integration-free transduction } \\
\hline $\begin{array}{l}\text { Fibroblasts (BJ and } \\
\text { MRC- } 5 \text { cells) }\end{array}$ & Hepatocytes & $\begin{array}{l}\text { HNF1A and Any two of the three } \\
\text { factors: FOXA1, FOXA3, and } \\
\text { HNF4A (mRNA transfection) }\end{array}$ & Human & & 2014 & $24963715^{59)}$ \\
\hline $\begin{array}{l}\text { Non-sensory cochlear } \\
\text { epithelial cells }\end{array}$ & Neuronal cells & $\begin{array}{l}\text { Ascl1; Ascl1 and Neurod (plasmid } \\
\text { electroporation) }\end{array}$ & Mouse & & 2014 & $24928351^{39)}$ \\
\hline Cardiac fibroblasts & Cardiomyocytes & $\begin{array}{l}\text { Gata4, Mef2c, and Tbx5 (peptide- } \\
\text { enhanced mRNA transfection) }\end{array}$ & Mouse & & 2015 & $25834424^{116)}$ \\
\hline Astrocytes & Neural stem cells & Sox2 (Leu3p- $\alpha$ IPM system) & Mouse & & 2016 & $27148066^{121)}$ \\
\hline $\begin{array}{l}\text { Fetal and embryonic } \\
\text { fibroblasts and Brain } \\
\text { cells in vivo }\end{array}$ & Neuronal cells & $\begin{array}{l}\text { Ascl1, Brn2, and Myt1l (mRNA } \\
\text { transfection with a GO-PEI-based } \\
\text { reagent in vitro and in vivo) }\end{array}$ & $\begin{array}{l}\text { Mouse \& } \\
\text { Human }\end{array}$ & & 2016 & $28145631^{40)}$ \\
\hline $\begin{array}{l}\text { Peripheral blood mono- } \\
\text { nuclear cells }\end{array}$ & $\begin{array}{l}\text { Photoreceptor } \\
\text { cells }\end{array}$ & $\begin{array}{l}\text { CRX, RAX1, and NEUROD1 } \\
\text { (SeV infection) }\end{array}$ & Human & & 2016 & $27170256^{112)}$ \\
\hline $\begin{array}{l}\text { Gingival fibroblasts and } \\
\text { Adult dermal fibroblasts }\end{array}$ & Osteoblasts & $\begin{array}{l}\text { OCT4, OSTERIX, and L-MYC } \\
\text { (plasmid transfection) }\end{array}$ & Human & YES & 2016 & $26990860^{81)}$ \\
\hline Fibroblasts & Hepatocytes & $\begin{array}{l}\text { OCT4, FOXA2, HNF1A, and } \\
\text { GATA3 (protein transduction } \\
\text { with HVJ-E) }\end{array}$ & Human & & 2017 & $28587331^{62)}$ \\
\hline Fibroblasts & Neurocytes & $\begin{array}{l}\text { SOX2, GATA3, and NEUROD1 } \\
\text { (protein transduction with HVJ- } \\
\text { E) }\end{array}$ & Human & & 2017 & $28587331^{62)}$ \\
\hline Fibroblasts (3T6 cells) & Neuronal cells & $\begin{array}{l}\text { Ascl1, Brn2, and Foxa1 (plasmid } \\
\text { transfection with a polysacchar- } \\
\text { ide-based reagent) }\end{array}$ & Mouse & & 2017 & $28855426^{119)}$ \\
\hline Mesenchymal stem cells & Hepatocytes & $\begin{array}{l}\text { Hnf4a and Foxa3 (PiggyBac } \\
\text { transposon) }\end{array}$ & Mouse & & 2017 & $28295042^{114)}$ \\
\hline Dermal fibroblasts & $\begin{array}{l}\text { Endothelial pro- } \\
\text { genitor cells }\end{array}$ & ETV2 (mRNA transfection) & Human & YES & 2017 & $27778229^{117)}$ \\
\hline Fibroblasts (3T6 cells) & Neuronal cells & $\begin{array}{l}\text { Ascl1, Brn4, and Tcf3 (plasmid } \\
\text { transfection with a polysacchar- } \\
\text { ide-based reagent) }\end{array}$ & Mouse & & 2017 & $29137640^{120)}$ \\
\hline $\begin{array}{l}\text { Mesenchymal stem cells } \\
\text { and Dermal fibroblasts }\end{array}$ & Neural stem cells & SOX2 (mRNA transfection) & Human & & 2018 & $29909688^{118)}$ \\
\hline Adult fibroblasts & $\begin{array}{l}\text { Neural precursor } \\
\text { cells }\end{array}$ & $\begin{array}{l}\text { SOX2; SOX2 and PAX6; SOX2 } \\
\text { and LMX1A; SOX2, LMX1A, and } \\
\text { FOXA2 (plasmid transfection) }\end{array}$ & Human & & 2018 & $30018471^{36)}$ \\
\hline Dermal fibroblasts & $\begin{array}{l}\text { Neural precursor } \\
\text { cells }\end{array}$ & $\begin{array}{l}\text { SOX2 and PAX6 (chemically } \\
\text { modified mRNA or plasmid } \\
\text { transfection) }\end{array}$ & Human & & 2018 & $30450440^{34)}$ \\
\hline Embryonic fibroblasts & Hepatocytes & $\begin{array}{l}\text { Hnf4a and Foxa3 (modified } \\
\text { mRNA transfection) }\end{array}$ & Mouse & YES & 2018 & $30327781^{115)}$ \\
\hline
\end{tabular}


Continued.

\begin{tabular}{|c|c|c|c|c|c|c|}
\hline Foreskin fibroblasts & Neuronal cells & $\begin{array}{l}\text { ASCL1 + miR-124 + P53 knock- } \\
\text { down (episomal plasmid } \\
\text { transfection) }\end{array}$ & Human & & 2019 & $30539819^{122)}$ \\
\hline $\begin{array}{l}\text { Bone marrow-derived } \\
\text { cells, Fibroblasts, and } \\
\text { Keratinocytes } \\
\end{array}$ & $\begin{array}{l}\text { Neural precursor } \\
\text { cells }\end{array}$ & $\begin{array}{l}\text { MSI1, NGN2, and MBD2 } \\
\text { (plasmid transfection) }\end{array}$ & Human & YES & 2019 & $31196173^{37)}$ \\
\hline $\begin{array}{l}\text { Renal proximal tubular } \\
\text { epithelial (HK2) cells }\end{array}$ & $\begin{array}{l}\text { Nephron progen- } \\
\text { itor cells }\end{array}$ & $\begin{array}{l}\text { SNAI2, EYA1, and SIX1 } \\
\text { (PiggyBac transposon) }\end{array}$ & Human & & 2019 & $30827514^{103)}$ \\
\hline \multicolumn{7}{|c|}{ Chemical compounds (with or without transcription factors) } \\
\hline $\begin{array}{l}\text { Fibroblasts (IMR90 or } \\
\text { MRC5 cells) }\end{array}$ & $\begin{array}{l}\text { Cholinergic } \\
\text { neurons }\end{array}$ & $\begin{array}{l}\text { NGN2 + Forskolin and dorso- } \\
\text { morphin treatment }\end{array}$ & Human & & 2013 & $23873306^{130)}$ \\
\hline $\begin{array}{l}\text { Embryonic fibroblasts } \\
\text { and Neonatal tail-tip } \\
\text { fibroblasts }\end{array}$ & Cardiomyocytes & $\begin{array}{l}\text { CHIR99021, RepSox, Forskolin, } \\
\text { Valproic acid, Parnate, and } \\
\text { TTNPB treatment }\end{array}$ & Mouse & & 2015 & $26292833^{123)}$ \\
\hline $\begin{array}{l}\text { Embryonic fibroblasts } \\
\text { and Adult tail-tip fibro- } \\
\text { blasts }\end{array}$ & Neural stem cells & $\begin{array}{l}\text { Valproic acid, Bix01294, RG108, } \\
\text { PD0325901, CHIR99021, Vitamin } \\
\text { C, and A83-01 treatment }\end{array}$ & Mouse & YES & 2015 & $26788068^{124)}$ \\
\hline Fibroblasts & Neuronal cells & $\begin{array}{l}\text { Valproic acid, CHIR99021, } \\
\text { RepSox, Forskolin, SP600125, } \\
\text { GO6983, and Y-27632 treatment }\end{array}$ & Human & & 2015 & $26253202^{125)}$ \\
\hline Fibroblasts & Neuronal cells & $\begin{array}{l}\text { ISX9, SB431542, Forskolin, } \\
\text { CHIR99021, and I-BET151 } \\
\text { treatment }\end{array}$ & Mouse & & 2015 & $26253201^{126)}$ \\
\hline Embryonic fibroblasts & Neural stem cells & $\begin{array}{l}\text { A83-01, Purmorphamine, } \\
\text { Valproic acid, and Thiazovivin } \\
\text { treatment }\end{array}$ & Mouse & & 2017 & $27207831^{131)}$ \\
\hline Urine-derived cells & Hepatocytes & $\begin{array}{l}\text { FOXA3 and HNF1A or } \\
\text { HNF4A + CHIR99021, RepSox, } \\
\text { Valproic acid, Parnate, TTNPB, } \\
\text { and Dznep treatment }\end{array}$ & Human & & 2018 & $30315254^{127)}$ \\
\hline $\begin{array}{l}\text { Embryonic and adult } \\
\text { fibroblasts }\end{array}$ & $\begin{array}{l}\text { Skeletal muscle } \\
\text { progenitor cells }\end{array}$ & $\begin{array}{l}\text { Myod + CHIR99021, RepSox, } \\
\text { and Forskolin treatment }\end{array}$ & Mouse & YES & 2018 & $29742392^{128)}$ \\
\hline $\begin{array}{l}\text { Adult dermal fibro- } \\
\text { blasts, Fetal pancreas } \\
\text { fibroblasts, and } \\
\text { Peripheral blood mono- } \\
\text { nuclear cells }\end{array}$ & $\begin{array}{l}\text { Neural plate bor- } \\
\text { der stem cells }\end{array}$ & $\begin{array}{l}\text { BRN2, KLF4, SOX2, and ZIC3 + } \\
\text { CHIR99021, ALK5 inhibitor, } \\
\text { Purmorphamine, Tranylcypro- } \\
\text { mine treatment }\end{array}$ & Human & YES & 2018 & $30581079^{132)}$ \\
\hline Striatal neurons & $\begin{array}{l}\text { Dopaminergic } \\
\text { neurons }\end{array}$ & $\begin{array}{l}\text { Sox } 2, \text { Nurr1, Lmx1a, and } \\
\text { Foxa } 2+\text { Valproic acid treatment } \\
\text { (in vivo infection) }\end{array}$ & Mouse & & 2018 & $30318292^{42)}$ \\
\hline $\begin{array}{l}\text { Glioblastoma cells } \\
\text { (U87MG cells) }\end{array}$ & Neuronal cells & $\begin{array}{l}\text { Forskolin, ISX9, CHIR99021, } \\
\text { I-BET151, and DAPT treatment }\end{array}$ & Human & & 2018 & $30091580^{129)}$ \\
\hline Dermal fibroblasts & Neuronal cells & $\begin{array}{l}\text { NGN2 and ASCL1 + Pyrintegrin, } \\
\text { ZM336372, AZ960, and KC7F2 } \\
\text { treatment }\end{array}$ & Human & & 2019 & $31099332^{133)}$ \\
\hline
\end{tabular}


Continued.

\begin{tabular}{|c|c|c|c|c|c|c|}
\hline \multicolumn{7}{|c|}{ Culture condition and soluble factors (with transcription factors) } \\
\hline Liver cells in vivo & $\beta$ cells & $\begin{array}{l}\text { PDX1 + EGF and nicotinamide } \\
\text { treatment }\end{array}$ & Human & YES & 2005 & $15899968^{134)}$ \\
\hline $\begin{array}{l}\text { Adult dermal fibroblasts } \\
\text { and Neonatal foreskin } \\
\text { fibroblasts }\end{array}$ & $\begin{array}{l}\text { Multilineage } \\
\text { blood progenitor } \\
\text { cells }\end{array}$ & $\begin{array}{l}\text { OCT } 4+\text { hematopoietic cytokines } \\
\text { treatment }\end{array}$ & Human & YES & 2010 & $21057492^{135)}$ \\
\hline Embryonic fibroblasts & Cardiomyocytes & $\begin{array}{l}\text { OSKM + cytokines (including } \\
\text { Bmp4) treatment }\end{array}$ & Mouse & & 2011 & $21278734^{136)}$ \\
\hline Adult skin fibroblasts & Neural stem cells & OSKM + neurosphere culture & Mouse & YES & 2012 & $22467474^{137)}$ \\
\hline Amniocytes & $\begin{array}{l}\text { Vascular endo- } \\
\text { thelial cells }\end{array}$ & $\begin{array}{l}\text { ETV2, FLI1, and ERG1 }+\mathrm{TGF} \beta \\
\text { inhibitor treatment }\end{array}$ & Human & YES & 2012 & $23084400^{139)}$ \\
\hline $\begin{array}{l}\text { Embryonic stem cells- } \\
\text { derived fibroblasts }\end{array}$ & Neural crest cells & $\begin{array}{l}\text { SOX10 + Environmental cues } \\
\text { including WNT activation }\end{array}$ & Human & YES & 2014 & $25158936^{140)}$ \\
\hline Newborn fibroblasts & Hepatocytes & OSK + Soluble factors & Human & YES & 2014 & $24572354^{226)}$ \\
\hline Dermal fibroblasts & $\begin{array}{l}\text { Oligodendrocyte } \\
\text { progenitor cells }\end{array}$ & Oct $4+$ OPC induction medium & Mouse & YES & 2015 & $26497893^{141)}$ \\
\hline Embryonic fibroblasts & Keratinocytes & OSK + Bmp4 and RA treatment & Mouse & YES & 2016 & $27473056^{142)}$ \\
\hline Skin fibroblasts & Neural stem cells & $\begin{array}{l}\text { OCT3/4, SOX2, KLF4, L-MYC, } \\
\text { and LIN28 + P53 knockdown + } \\
\text { Neurotrophins treatment }\end{array}$ & Human & & 2016 & $27822179^{138)}$ \\
\hline \multicolumn{7}{|c|}{ miRNAs (with or without transcription factors) } \\
\hline Cardiac fibroblasts & Cardiomyocytes & $\begin{array}{l}\text { miR-1, miR-133, miR-208, and } \\
\text { miR-499 }\end{array}$ & Mouse & & 2012 & $22539765^{147)}$ \\
\hline Embryonic fibroblasts & Neuronal cells & Ptb knockdown & Mouse & & 2013 & $23313552^{143)}$ \\
\hline $\begin{array}{l}\text { Cardiac fibroblasts and } \\
\text { Embryonic fibroblasts }\end{array}$ & Cardiomyocytes & $\begin{array}{l}\text { Gata4, Mef2c, and Tbx5 + miR- } \\
\text { 133; Gata4, Mef2c, Tbx5, Mesp1, } \\
\text { and Myocd + miR-133 }\end{array}$ & $\begin{array}{l}\text { Mouse \& } \\
\text { Human }\end{array}$ & & 2014 & $24920580^{148)}$ \\
\hline $\begin{array}{l}\text { Adult dermal fibro- } \\
\text { blasts, Umbilical cord } \\
\text { blood cells, and Senes- } \\
\text { cent somatic cells } \\
\end{array}$ & Neural stem cells & $\begin{array}{l}\text { SOX2 + HMGA2 expression or } \\
\text { LET-7B inhibition }\end{array}$ & Human & YES & 2015 & $25600877^{144)}$ \\
\hline Fibroblasts & Cardiomyocytes & $\begin{array}{l}\text { GATA4, MEF2C, TBX5, } \\
\text { ESRRG, MESP1, MYOCARDIN, } \\
\text { ZFPM2, and HAND2 + miR-1 }\end{array}$ & Human & & 2017 & $28796841^{149)}$ \\
\hline Adult fibroblasts & Neuronal cells & miR-9/9* and miR-124 & Human & & 2017 & $28886366^{145)}$ \\
\hline Adult fibroblasts & $\begin{array}{l}\text { Spinal cord } \\
\text { motor neurons }\end{array}$ & $\begin{array}{l}\text { ISL1 and LHX } 3+\text { miR-9/9* and } \\
\text { miR-124 }\end{array}$ & Human & & 2017 & $28886366^{145)}$ \\
\hline Brain vascular pericytes & $\begin{array}{l}\text { Cholinergic } \\
\text { neuronal cells }\end{array}$ & $\begin{array}{l}\text { ASCL1, MYT1L, BRN2, and } \\
\text { TLX3 + miR-124 }\end{array}$ & Human & YES & 2018 & $29453933^{146)}$ \\
\hline \multicolumn{7}{|c|}{ Physical stimulation (with or without transcription factors) } \\
\hline Embryonic fibroblasts & Neuronal cells & $\begin{array}{l}\text { Ascl1, Brn2, and Myt1l+ } \\
\text { Substrate topography }\end{array}$ & Mouse & & 2014 & $24709523^{153)}$ \\
\hline Fibroblasts & Cardiomyocytes & $\begin{array}{l}\text { Myocardin, Tbx } 5, \text { and Mef2c }+ \\
\text { Microgroove }\end{array}$ & Mouse & & 2015 & $26302234^{154)}$ \\
\hline
\end{tabular}


Continued.

\begin{tabular}{|c|c|c|c|c|c|c|}
\hline Embryonic fibroblasts & $\begin{array}{l}\text { Dopaminergic } \\
\text { neurons }\end{array}$ & $\begin{array}{l}\text { Ascl1, Pitx3, Nurr1, and Lmx1a + } \\
\text { Nanogroove }\end{array}$ & Mouse & & 2015 & $25662493^{155)}$ \\
\hline Dermal fibroblasts & $\begin{array}{l}\text { Endothelial pro- } \\
\text { genitor cells }\end{array}$ & ETV2 + Hypoxia & Human & & 2016 & $27488544^{151)}$ \\
\hline $\begin{array}{l}\text { Neonatal tail-tip fibro- } \\
\text { blasts }\end{array}$ & Cardiomyocytes & $\begin{array}{l}\text { Gata } 4 \text {, Mef2c, and Tbx } 5+ \\
\text { Microgroove }\end{array}$ & Mouse & & 2016 & $27376554^{156)}$ \\
\hline Fibroblasts & Cardiomyocytes & $\begin{array}{l}\text { Gata4, Mef2c, and Tbx } 5+ \\
\text { Hypoxia }\end{array}$ & Mouse & & 2016 & $26757100^{152)}$ \\
\hline Dermal fibroblasts & Chondrocytes & Electrical stimulation & Human & & 2019 & $31005261^{157)}$ \\
\hline \multicolumn{7}{|c|}{ CRISPR/Cas9-based methods } \\
\hline Embryonic fibroblasts & Neuronal cells & $\begin{array}{l}\text { CRISPR/Cas9-based transcrip- } \\
\text { tional activators + gRNAs for } \\
\text { Brn2, Ascl1, and Myt1l }\end{array}$ & Mouse & & 2016 & $27524438^{158)}$ \\
\hline Liver cells in vivo & $\beta$ cells & $\begin{array}{l}\text { CRISPR/Cas9-based transcrip- } \\
\text { tional activators + gRNA for } \\
\text { Pdx1 (in vivo infection) }\end{array}$ & Mouse & YES & 2017 & $29224783^{71)}$ \\
\hline \multicolumn{7}{|c|}{ Protein engineering (with transcription factors) } \\
\hline Embryonic fibroblasts & Cardiomyocytes & $\begin{array}{l}\text { Gata4, Tbx } 5 \text {, and Hand } 2+\text { Mef2c } \\
\text { fused with M3 domain of Myod }\end{array}$ & Mouse & & 2013 & $23794713^{159)}$ \\
\hline Astrocytes & Neuronal cells & Ascl1, Creb-VP16, and Icer & Mouse & & 2017 & $28321434^{160)}$ \\
\hline \multicolumn{7}{|c|}{ Other methods } \\
\hline $\begin{array}{l}\text { Bone marrow stromal } \\
\text { cells }\end{array}$ & $\begin{array}{l}\text { Renal proximal } \\
\text { tubular epithelial } \\
\text { cells }\end{array}$ & $\begin{array}{l}\text { HK2 cell-extracts treatment }+ \\
\text { streptolysin O }\end{array}$ & Human & YES & 2015 & $25754206^{161)}$ \\
\hline Embryonic fibroblasts & Cardiomyocytes & $\begin{array}{l}\text { Gata4, Hand2, Mef2c, and } \\
\text { Tbx } 5+\text { miR- } 1 \text { and miR- } 133+ \\
\text { TGF } \beta \text { inhibitors or ROCK } \\
\text { inhibitors }\end{array}$ & Mouse & & 2015 & $26354680^{162)}$ \\
\hline $\begin{array}{l}\text { Pancreatic exocrine } \\
\text { cells }\end{array}$ & $\beta$ cells & $\begin{array}{l}\text { Pdx1, Ngn3, and Mafa (synthetic } \\
\text { mRNA transfection) }+5 \text {-Aza } \\
\text { treatment }\end{array}$ & Mouse & & 2016 & $27187823^{163)}$ \\
\hline $\begin{array}{l}\text { Neonatal cardiac and } \\
\text { tail-tip fibroblasts }\end{array}$ & Cardiomyocytes & $\begin{array}{l}\text { miR-1, miR-133, miR-208, and } \\
\text { miR-499 + three-dimensional } \\
\text { culture }\end{array}$ & Mouse & & 2016 & $27941896^{164)}$ \\
\hline $\begin{array}{l}\text { Neonatal cardiac and } \\
\text { tail-tip fibroblasts }\end{array}$ & Cardiomyocytes & $\begin{array}{l}\text { miR-1, miR-133, miR-208, and } \\
\text { miR-499 + Reprogramming } \\
\text { medium }\end{array}$ & Mouse & & 2016 & $26975336^{165)}$ \\
\hline $\begin{array}{l}\text { Adipose-derived stem } \\
\text { cells and Neonatal } \\
\text { foreskin fibroblasts }\end{array}$ & Neural stem cells & $\begin{array}{l}\text { iPSC induction followed by } \\
\text { TRA-1-60-/SSEA4-selection }\end{array}$ & Human & YES & 2016 & $27569063^{166)}$ \\
\hline Fibroblasts & Adipocytes & $\begin{array}{l}\text { OCT4 and C/EBPB (protein } \\
\text { transduction with HVJ-E) }+ \\
\text { Adipogenic differentiation } \\
\text { medium }\end{array}$ & Human & & 2017 & $28587331^{62)}$ \\
\hline
\end{tabular}


section, a wide variety of technologies used in direct reprogramming studies are introduced.

3.1. Genome integration-free gene transduction. Even now, transcription factors are one of the most powerful and useful tools for direct reprogramming. Therefore, several genome integration-free transduction methods have been applied for direct reprogramming instead of conventional viral vectors, such as retrovirus and lentivirus vectors. Sendai virus ( $\mathrm{SeV}$; hemagglutinating virus of Japan, HVJ) is an RNA virus that does not enter the nucleus and replicates in the cytoplasm. Therefore, vector systems using this virus are not at risk of genome integration of the transgenes. In addition to the induction of iPSCs, ${ }^{111)} \mathrm{SeV}$ vectors have been used for direct induction of photoreceptor cells from peripheral blood cells. ${ }^{112)}$ Additionally, a method for in vivo cardiac reprogramming using $\mathrm{SeV}$ vectors achieved high reprogramming efficiency. ${ }^{113)}$ These results suggested that the $\mathrm{SeV}$ vector system can be an alternative tool to induce cellular reprogramming based on the gene transduction method. Moreover, the envelope particle of the virus (HVJ-E) is a useful carrier of genes, siRNAs, proteins, and drugs. Human hepatocytes and neurocytes were induced from fibroblasts through the protein transduction technique with the HVJ-E carrier. ${ }^{62)}$ The PiggyBac system is a transposon-based gene transduction technique. Although transgenes are integrated into the host genome, these sequences can be removed without any footprints with transposase. Some studies have employed this system and induced mouse hepatocytes ${ }^{114}$ ) and human nephron progenitor cells from somatic cells. ${ }^{103)}$ mRNA transfection is an alternative gene transduction technique that is safer than previous methods. Since higher animals, including humans, do not have reverse transcriptase, there are no risks of integration of the transduced mRNAs into their genome. Many studies using mRNA transduction have been reported, e.g., hepatocytes, ${ }^{59), 115)}$ cardiomyocytes, ${ }^{116)}$ neuronal cells, ${ }^{40)}$ endothelial progenitor cells, ${ }^{117}$ ) and neural stem/ precursor cells. ${ }^{34), 118)}$ Nevertheless, several difficulties of this method, such as stability and transfection efficiency, remain. Solutions to these difficulties, such as the chemical modification of the mRNA ${ }^{34), 115)}$ and specific transfection reagents, ${ }^{40), 116)}$ have already been adopted in mRNA transfection studies. In addition to these methods, plasmid transfection has also been widely tested. ${ }^{27), 29), 32), 78), 116), 117)}$ Although there is a risk of genome integration and a problem of low transduction efficiency, novel tools, such as a polysaccharide-based gene co-delivery system, ${ }^{119), 120)}$ a Leu3p- $\alpha$ IPM system, ${ }^{121)}$ or episomal vectors, ${ }^{122)}$ might improve the plasmid-based transduction technologies.

3.2. Chemical compounds. Small chemical compounds that work as agonists or antagonists for various cellular reactions, such as signal transduction, the cell cycle, post-translational modification, apoptosis, epigenetics, and metabolism, have many advantages compared with gene transduction methods: 1) They are relatively more stable than biomolecules in vitro and in vivo. If they are not stable, chemical modifications can improve their stability. 2) Most can penetrate cells or organelles, unlike biopolymers. 3) There is no risk of genome integration of foreign sequences. 4) Suitable conditions for the chemicals are flexible and controllable.

Most chemicals used in the direct reprogramming studies have positive or negative effects for various signal transduction pathways, e.g., Wnt (CHIR99021), ${ }^{123)-129)}$ cAMP (Forskolin), ${ }^{123), 125), 126), 128)-130)}$ TGF $\beta \quad$ (RepSox, A83-01, SB431542), ${ }^{123)-128), 131)} \mathrm{Ca}^{2+}$ (ISX9), ${ }^{126), 129)}$ Shh

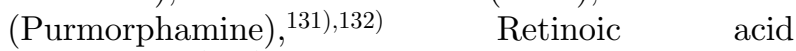


SP600125), ${ }^{125), 133)}$ Notch (DAPT), ${ }^{129)}$ AMPK (dorsomorphin), ${ }^{130)}$ PCK $\quad$ (GO6983), ${ }^{125)}$ HIF (KC7F2), ${ }^{133)}$ MAPK (PD0325901, ZM336372), ${ }^{124), 133)} \beta 1$-integrin (Pyrintegrin), ${ }^{133)}$ and Rho/ROCK (Thiazovivin, Y-27632) ${ }^{125), 131)}$ signaling pathways, and epigenetic modifications, e.g., histone lysine deacetylation (Valproic acid), ${ }^{42), 123)-125), 127), 131)}$ histone lysine acetylation recognition (IBET151), ${ }^{126), 129)}$ histone lysine methylation (Bix01294, Dznep), 124),127) DNA methylation (RG108), ${ }^{124)}$ and DNA demethylation (Vitamin C). ${ }^{124)}$ Although several types of cells, such as neuronal cells, hepatocytes, cardiomyocytes, and skeletal muscle progenitor cells, have been induced with chemicals, half of the reported studies used gene transduction in conjunction with the chemical treatments. ${ }^{42), 127), 128), 130), 132), 133)}$ Precise analysis of the functions of each transcription factor is required to compensate their functions with chemical compounds.

3.3. Partial reprogramming with specific culture conditions. Some studies have utilized gene transduction combinations and external signals from culture media. In particular, initializing factors of iPSCs have frequently been used in combination with external signals. A wide variety of cells, e.g., $\beta$ cells, ${ }^{134)}$ blood progenitor cells, ${ }^{135)}$ cardiomyo- 
cytes, ${ }^{136)}$ neural stem cells, ${ }^{137), 138)}$ vascular endothelial cells, ${ }^{139)}$ neural crest cells, ${ }^{140)}$ hepatocytes, ${ }^{140}$ ) oligodendrocyte progenitor cells, ${ }^{141)}$ and keratinocytes, ${ }^{142)}$ were previously generated and transplanted into model animals. Although these protocols are time- and cost-effective compared with iPSC-employing methods, the risk of tumorigenesis caused by cell initialization remains to be elucidated.

3.4. MicroRNAs (miRNAs). miRNAs regulate the expression of specific mRNAs post-transcriptionally. Therefore, miRNAs can be used for direct reprogramming instead of or in combination with gene transduction. In a previous study, somatic cells were converted into several types of neuronal cells $^{143)-146)}$ and cardiomyocytes. ${ }^{147)-149)}$ miRNA induction avoids the problem of transgene genome integration because the miRNA genes can be induced into cells as RNA. However, most of the reported studies employed gene transduction simultaneously for conversion. Complete miRNA-based reprogramming methods are expected to be developed in future.

3.5. Physical stimulations. Several physical stimulations have been used as additional stimulations for direct reprogramming. Hypoxia conditions have been frequently employed in stem cell biology and control stem cell functions through the HIF signaling pathway. ${ }^{150)}$ In a study involving direct reprogramming, these conditions were also used to accelerate conversion. ${ }^{151), 152)}$ On the other hand, micro- or nano-imprinted patterns, e.g., microgrooves, of cultured cell substrates are known as enhancers of reprogramming in biomaterials science. Biochemical and molecular biology studies are required to understand the effect of imprinted patterns for reprogramming. ${ }^{153)-156)}$ Of note, the electrical stimulation-induced direct reprogramming of fibroblasts into chondrocytes without any soluble factors or transgenes was reported recently. ${ }^{157)}$ Elucidating the molecular mechanism of the reprogramming phenomenon may aid in the development of direct reprogramming technology.

3.6. Other methods. Several other innovative approaches have been applied in direct reprogramming studies, such as a CRISPR/Cas9-based method. A modified Cas9 protein, which has a domain for transcriptional activation and guides RNAs for the endogenous transcription factor genes, is introduced into source cells to activate endogenous transcription factors. ${ }^{71), 158)}$ The genome integration-free protocols of the CRISPR/Cas9 system have already been established, thus, this method is also an integration-free method. Studies utilizing CRISPR-based direct reprogramming will increase because this method is straightforward and suitable for screening reprogramming factors.

Rational protein engineering of transcription factors is a unique approach translated from another field, i.e., biomolecular engineering. Functional protein domains, such as VP16 or M3 of Myod, are attached to transcription factors to improve their transcriptional activities. Neuronal cells and cardiomyocytes have been induced successfully by using artificial transcription factors. ${ }^{159), 160)}$

Additionally, the number of hybrid methods using the techniques above are increasing. ${ }^{161)-166)}$ In future, engineering-based approaches optimizing the reprogramming process will be considerably more important compared with previous stages.

\section{Mechanism analyses and future applications of direct reprogramming}

To make direct reprogramming technology more efficient and safer for medical and industrial applications, analyses of the molecular and cellular mechanisms of cell fate conversion, i.e., the transition of the transcriptome, the behavior of transcription factors, epigenetic remodeling, and the heterogeneity of cell populations, are essential (Fig. 2). In addition, applied research on direct reprogramming technology in medicine and industry has increased in recent years toward practical use (Table 3). Therefore, representatives of molecular and cellular mechanism analyses are introduced in this section. In addition, novel applications of direct reprogramming, including non-medical uses, are described.

4.1. Analyses of the molecular and cellular mechanisms of direct reprogramming. Regarding the mechanisms of direct cell fate conversion, the reprogramming processes of cardiomyocytes, ${ }^{148), 149), 165), 167)-179) \quad \text { neuronal }}$ cells, ${ }^{39), 45), 48), 143), 145), 160), 180)-188 \text { ) and hepato- }}$ cytes $^{189)-192)}$ have been well-studied among the various direct reprogramming methods. Additionally, several studies regarding the direct reprogramming of other cell types, e.g., neural stem/progenitor cells, ${ }^{193), 194)}$ glial cells, ${ }^{195)}$ photoreceptor cells, ${ }^{196)} \beta$ cells, ${ }^{197)}$ renal tubular epithelial cells, ${ }^{198)}$ trophoblast stem cells, ${ }^{102)}$ and mesodermal cells, ${ }^{199), 200)}$ have been reported.

Several methodologies have been employed for the molecular biological analysis of direct reprogramming. Comprehensive transcriptome analyses using RNA-seq have been performed frequently, and differential expression gene analysis between 
Behavior of the transcription factors

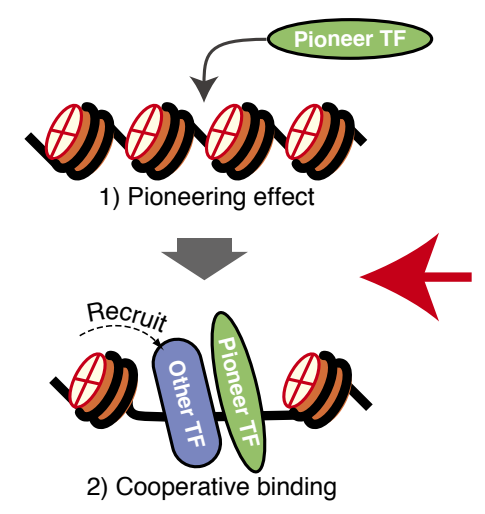

Single-cell analysis
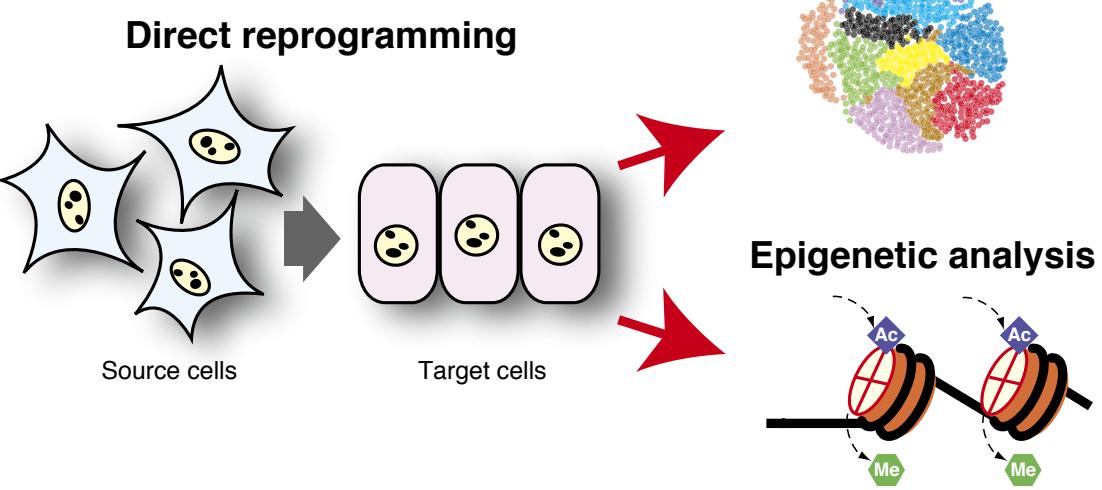

Fig. 2. (Color online) Different study types for direct reprogramming. Typical study types for direct reprogramming are indicated. Cutting-edge biochemistry and cell biology techniques have been employed for direct reprogramming studies. TF: transcription factor.

Table 3. Applications of the directly reprogrammed cells

\begin{tabular}{|c|c|c|c|c|c|}
\hline Source cells & Target cells & Transgenes and/or Treatment & Species & $\begin{array}{l}\text { Published } \\
\text { year }\end{array}$ & PMID \\
\hline \multicolumn{6}{|c|}{ In vivo reprogramming (regenerative medicine) } \\
\hline Liver cells & $\beta$ cells & Pdx1 (an adenoviral vectors) & Mouse & 2000,2003 & $\begin{array}{l}10802714^{20)} \\
12775714^{21)}\end{array}$ \\
\hline $\begin{array}{l}\text { Pancreatic exocrine } \\
\text { cells }\end{array}$ & $\beta$ cells & Ngn3, Pdx1, and Mafa (an adenoviral vector) & Mouse & 2008 & $18754011^{65)}$ \\
\hline Cardiac fibroblasts & Cardiomyocytes & $\begin{array}{l}\text { Gata } 4, \text { Mef2c, Tbx5, and Hand2 (a retrovirus } \\
\text { vector) }\end{array}$ & Mouse & 2012 & $22660318^{50)}$ \\
\hline Cardiac fibroblasts & Cardiomyocytes & $\begin{array}{l}\text { miR-1, miR-133, miR-208, and miR-499 } \\
\text { (a lentiviral vector) }\end{array}$ & Mouse & 2012 & $22539765^{54)}$ \\
\hline $\begin{array}{l}\text { Non-sensory cochlear } \\
\text { epithelial cells }\end{array}$ & Neuronal cells & $\begin{array}{l}\text { Ascl1; Ascl1 and Neurod (in vivo plasmid } \\
\text { electroporation) }\end{array}$ & Mouse & 2014 & $24928351^{39)}$ \\
\hline $\begin{array}{l}\text { Liver cells in mouse } \\
\text { models of chronic } \\
\text { liver disease }\end{array}$ & Hepatocytes & $\begin{array}{l}\text { Foxa3, Gata4, Hnf1a, and Hnf4a (an AAV } \\
\text { vector) }\end{array}$ & Mouse & 2016 & $26923201^{60)}$ \\
\hline Brain cells in vivo & Neuronal cells & $\begin{array}{l}\text { Ascl1, Brn2, and Myt1l (mRNA transfection } \\
\text { with a GO-PEI-based reagent) }\end{array}$ & Mouse & 2016 & $28145631^{40)}$ \\
\hline Bile duct cells & $\beta$ cells & Pdx1, Ngn3, and Mafa (an adenoviral vector) & Mouse & 2017 & $28363269^{69)}$ \\
\hline Hepatocytes & $\beta$ cells & $\begin{array}{l}\text { Pdx1, Ngn3, and Mafa (hydrodynamics tail } \\
\text { vein injection) }\end{array}$ & Mouse & 2017 & $28100871^{70)}$ \\
\hline Resident glial cells & Neuronal cells & Ascl1, Lmx1a, and Nurr1 (an AAV vector) & Mouse & 2017 & $28844658^{41)}$ \\
\hline Liver cells in vivo & $\beta$ cells & $\begin{array}{l}\text { CRISPR/Cas9-based transcriptional activa- } \\
\text { tors + gRNA for Pdx1 (an AAV vector) }\end{array}$ & Mouse & 2017 & $29224783^{71}$ \\
\hline Striatal neurons & Dopaminergic neurons & $\begin{array}{l}\text { Sox2, Nurr1, Lmx1a, and Foxa2 (a lentiviral } \\
\text { vector) + Valproic acid treatment }\end{array}$ & Mouse & 2018 & $30318292^{42)}$ \\
\hline Resident glial cells & Interneurons & Ascl1, Lmx1a, and Nurr1 (an AAV vector) & Mouse & 2019 & $31259901^{43)}$ \\
\hline
\end{tabular}


Continued.

\begin{tabular}{|c|c|c|c|c|c|}
\hline Microglial cells & Neuronal cells & Neurod1 (a lentiviral vector) & Mouse & 2019 & $30638745^{44)}$ \\
\hline \multicolumn{6}{|c|}{ Disease model } \\
\hline $\begin{array}{l}\text { Fibroblasts from } \\
\text { Huntington's disease } \\
\text { patients }\end{array}$ & Neuronal cells & PTB1 knockdown & Human & 2014 & $25275533^{45)}$ \\
\hline $\begin{array}{l}\text { Urine-derived cells } \\
\text { from muscle diseases } \\
\text { patients }\end{array}$ & Skeletal muscle cells & MYOD & Human & 2016 & $27651888^{104)}$ \\
\hline $\begin{array}{l}\text { TSC2 gene-inactivated } \\
\text { fibroblasts (CRISPR } \\
\text { knockout) }\end{array}$ & Neuronal cells & ASCL1, LMX1A, and NURR1 & Human & 2016 & $27857203^{207)}$ \\
\hline $\begin{array}{l}\text { Adult skin fibroblasts } \\
\text { from ALS patients }\end{array}$ & Motor neurons & NEUROG2, SOX11, ISL1, and LHX3 & Human & 2016 & $26725112^{46)}$ \\
\hline $\begin{array}{l}\text { Dermal fibroblasts } \\
\text { from metabolic disease } \\
\text { patients }\end{array}$ & Adipocytes & PPARG2 & Human & 2017 & $28982679^{88)}$ \\
\hline $\begin{array}{l}\text { Fibroblasts from BMD } \\
\text { patients }\end{array}$ & Skeletal muscle cells & MYOD & Human & 2018 & $30171539^{105)}$ \\
\hline $\begin{array}{l}\text { Fibroblasts from } \\
\text { MERRF patients }\end{array}$ & Neuronal cells & $\begin{array}{l}\text { ASCL1 and BRN2 + REST complex } \\
\text { knockdown }\end{array}$ & Human & 2019 & $30797798^{47)}$ \\
\hline \multicolumn{6}{|c|}{ Other animals } \\
\hline Embryonic fibroblasts & Neuronal cells & ASCL1, BRN2, MYT1L, and NEUROD1 & Marmoset & 2014 & $24694048^{211)}$ \\
\hline Skin fibroblasts & Cardiomyocytes & GATA4, HAND2, TBX5, and MEF2C & Canine & 2015 & $26681949^{209)}$ \\
\hline Cardiac fibroblasts & Cardiomyocytes & Gata4, Mef2c, and Tbx5 + miR-590 & $\begin{array}{l}\text { Rat, Porcine, } \\
\text { \& Human }\end{array}$ & 2016 & $27930352^{208)}$ \\
\hline Fetal fibroblasts & $\begin{array}{l}\text { Cardiomyocytes, } \\
\text { Neurocytes, Oocytes, } \\
\text { and Cumulus } \\
\text { granulosa cells }\end{array}$ & OSKM + Lineage-specific medium & Goat & 2017 & $27629151^{210)}$ \\
\hline \multicolumn{6}{|c|}{ Drug discovery } \\
\hline Embryonic stem cells & Neuronal cells & NGN2 & Human & 2019 & $31155484^{48)}$ \\
\hline
\end{tabular}

source and target cells has provided a considerable amount of information regarding essential regulator genes and signaling pathways during conversion. ${ }^{143), 148), 176), 179), 180), 200)}$ Epigenetic remodeling studies during cell-fate conversions have also been performed in various reprogrammed cells. $^{44), 48), 171), 175), 177), 182), 188), 191), 194), 195)}$ Histone modification and DNA methylation data clarified the drastic and rapid change in chromatin states in reprogrammed cells. In addition, detailed analysis of transduced and endogenously upregulated transcription factors was a critical task for understanding direct reprogramming. Several methods, such as loss-of-function, ChIP-seq, and mass spectro- metry, have been used to analyze the function and behavior of transcription factors. 102), 145), 160), 167), 169),172), 173), 179),184)-186),190), 195), 199) Transcription factor studies indicated that almost all of the reprogramming-related transcription factors played vital roles during the reprogramming process, e.g., by remodeling histone and DNA modifications, initiating the target transcription network, and erasing the transcriptional signature of the source cells. Recently, the activities of specific transcription factors, termed pioneer factors, seem pivotal for remodeling the chromatin states of cell conversion. $^{201)}$ For example, Ascl1 was identified as a pioneer factor for the induction of iN cells, which 
can preferentially bind to chromatin and allowed the binding of other reprogramming factors used for iN cell induction. ${ }^{202)}$ Additionally, in the case of iHep cell induction, well-known pioneer factors from the Foxa protein family are indispensable. ${ }^{55), 56), 58)-64), 114), 115), 127), 189)}$ Therefore, understanding the roles of pioneer factors will improve direct reprogramming technology. Additionally, the function of miRNA in iCMs has been thoroughly analyzed, and, therefore, miRNA-based reprogramming technologies of iCMs have been developed. ${ }^{148), 165), 177)}$ The analysis of miRNAs in other direct reprogramming methods may result in their improvement. Other molecular and cellular analyses, such as signal transduction, ${ }^{174), 183), 197)}$ metabolic remodeling, ${ }^{198)}$ time-lapse imaging, ${ }^{170)}$ and cell morphological studies, ${ }^{168)}$ have been performed. Recently, single-cell analyses, such as single-cell RNA sequencing (scRNA-seq), have been performed in many direct reprogramming studies. ${ }^{149), 181), 187), 192), 199)}$ These studies have clarified many features of direct reprogramming processes. For example, a limiting step and an obstruction factor, ${ }^{187)}$ a stem cell-like transition state, ${ }^{181)}$ and multiple trajectories ${ }^{192)}$ of the direct cell fate conversions were discovered using scRNA-seq data. In the near future, other single-cell analysis techniques, such as ATAC-seq, ${ }^{203)}$ ChIL-seq, ${ }^{204)}$ CUT\&RUN, ${ }^{205)}$ and $\mathrm{Hi}-\mathrm{C},{ }^{206)}$ will reveal the chromatin dynamics and epigenetic remodeling processes in single converting cells during direct reprogramming processes.

4.2. Medical and industrial applications of direct reprogramming. As described above, most applied research for direct reprogramming has focused on clinical medicine, i.e., cell transplantation and in vivo direct reprogramming therapies. Meanwhile, some non-medical applications have been reported in recent years (Table 3). Direct reprogramming studies of disease model cells, which are induced from patient-derived cells, are necessary for basic studies of different disorders, and these cells can be employed for in vitro experiments for drug discovery. Indeed, a human iN cell type, instead of primary neuronal cells, was previously applied to in vitro drug treatment experiments. ${ }^{48)}$ Additionally, several directly induced neuronal and skeletal muscle cell types from patients with various diseases have been reported. ${ }^{45)-47), 104), 105), 207)}$ Direct reprogramming technology has the potential to change the pharmaceutical industry. In direct reprogramming studies, cells from different species, e.g., rat ${ }^{208)}$ pigs, ${ }^{208)}$ dogs ${ }^{209)}$ goats, ${ }^{210)}$ and marmosets, ${ }^{211)}$ have been generated. Some of the animals studied were industrial animals, such as livestock or pets, since direct reprogramming technology might contribute to animal industries, such as veterinary medicine.

\section{Summary}

Direct reprogramming is a promising technology that can convert somatic cells into various terminally differentiated or somatic stem/progenitor cell types for medical and industrial applications. Therefore, the number of studies utilizing this technology has increased rapidly in the last decade. Artificial cell fate conversions can be achieved with the forced expression of defined sets of transcription factors, treatment with chemical compounds as agonists or antagonists for various bioreactions, culturing with soluble factors or specific culture conditions, the induction of miRNA sets, appropriate physical stimulations, among other methods. Various cell types have been induced from somatic cells through direct reprogramming. Among them, neuronal cells, cardiomyocytes, and hepatocytes have been well-studied and their reprogramming mechanisms have been thoroughly analyzed. These technologies are expected to be applied in a variety of industries such as agriculture, biomaterial, healthcare, and medical industries.

\section{Acknowledgments}

This work was supported in part by the JSPS KAKENHI (Grant Numbers: JP16H01850, JP16K08592，JP18H05102，JP19H01177， and JP19H05267), the Core Research for Evolutional Science and Technology (CREST) Program of the Japan Agency for Medical Research and Development (AMED), the Program for Basic and Clinical Research on Hepatitis of AMED, the Practical Research Project for Rare/Intractable Diseases of AMED, the Research Center Network for Realization of Regenerative Medicine of AMED, the Takeda Science Foundation, the Uehara Memorial Foundation, and the Japan Intractable Diseases Research Foundation.

\section{References}

1) Waddington, C.H. (1957) The Strategy of the Genes. George Allen \& Unwin Ltd, London.

2) Poss, K.D., Wilson, L.G. and Keating, M.T. (2002) Heart regeneration in zebrafish. Science 298, 2188-2190.

3) Raya, A., Koth, C.M., Büscher, D., Kawakami, Y., Itoh, T., Raya, R.M. et al. (2003) Activation of notch signaling pathway precedes heart regeneration in zebrafish. Proc. Natl. Acad. Sci. U.S.A. 
100 (Suppl), 11889-11895.

4) McGann, C.J., Odelberg, S.J. and Keating, M.T. (2001) Mammalian myotube dedifferentiation induced by newt regeneration extract. Proc. Natl. Acad. Sci. U.S.A. 98, 13699-13704.

5) Takahashi, K. and Yamanaka, S. (2006) Induction of pluripotent stem cells from mouse embryonic and adult fibroblast cultures by defined factors. Cell 126, 663-676.

6) Garber, K. (2015) RIKEN suspends first clinical trial involving induced pluripotent stem cells. Nat. Biotechnol. 33, 890-891.

7) Morizane, A. (2019) Cell therapy for Parkinson's disease with induced pluripotent stem cells. Clin. Neurol. 59, 119-124.

8) Akabayashi, A., Nakazawa, E. and Jecker, N.S. (2019) The world's first clinical trial using iPS cell sheets for corneal epithelial stem cell deficiency. New Front. Ophthalmol. 5, 1-2.

9) Hino, K., Zhao, C., Horigome, K., Nishio, M., Okanishi, Y., Nagata, S. et al. (2018) An mTOR signaling modulator suppressed heterotopic ossification of fibrodysplasia ossificans progressiva. Stem Cell Rep. 11, 1106-1119.

10) Hosoya, M., Fujioka, M., Sone, T., Okamoto, S., Akamatsu, W., Ukai, H. et al. (2017) Cochlear cell modeling using disease-specific iPSCs unveils a degenerative phenotype and suggests treatments for congenital progressive hearing loss. Cell Rep. 18, 68-81.

11) Tabata, Y., Imaizumi, Y., Sugawara, M., AndohNoda, T., Banno, S., Chai, M.C. et al. (2018) Ttype calcium channels determine the vulnerability of dopaminergic neurons to mitochondrial stress in familial Parkinson disease. Stem Cell Rep. 11, $1171-1184$.

12) Kondo, T., Imamura, K., Funayama, M., Tsukita, K., Miyake, M., Ohta, A. et al. (2017) iPSCbased compound screening and in vitro trials identify a synergistic anti-amyloid $\beta$ combination for Alzheimer's disease. Cell Rep. 21, 2304-2312.

13) Egawa, N., Kitaoka, S., Tsukita, K., Naitoh, M., Takahashi, K., Yamamoto, T. et al. (2012) Drug screening for ALS using patient-specific induced pluripotent stem cells. Sci. Transl. Med. 4, $145 \mathrm{ra} 104$.

14) Li, H.L., Fujimoto, N., Sasakawa, N., Shirai, S., Ohkame, T., Sakuma, T. et al. (2015) Precise correction of the dystrophin gene in duchenne muscular dystrophy patient induced pluripotent stem cells by TALEN and CRISPR-Cas9. Stem Cell Rep. 4, 143-154.

15) Lancaster, M.A., Renner, M., Martin, C.A., Wenzel, D., Bicknell, L.S., Hurles, M.E. et al. (2013) Cerebral organoids model human brain development and microcephaly. Nature 501, 373-379.

16) Spence, J.R., Mayhew, C.N., Rankin, S.A., Kuhar, M.F., Vallance, J.E., Tolle, K. et al. (2011) Directed differentiation of human pluripotent stem cells into intestinal tissue in vitro. Nature 470, 105-110.

17) Takebe, T., Sekine, K., Enomura, M., Koike, H.,
Kimura, M., Ogaeri, T. et al. (2013) Vascularized and functional human liver from an iPSC-derived organ bud transplant. Nature 499, 481-484.

18) Taguchi, A., Kaku, Y., Ohmori, T., Sharmin, S., Ogawa, M., Sasaki, H. et al. (2014) Redefining the in vivo origin of metanephric nephron progenitors enables generation of complex kidney structures from pluripotent stem cells. Cell Stem Cell 14, $53-67$.

19) Davis, R.L., Weintraub, H. and Lassar, A.B. (1987) Expression of a single transfected cDNA converts fibroblasts to myoblasts. Cell 51, 987-1000.

20) Ferber, S., Halkin, A., Cohen, H., Ber, I., Einav, Y., Goldberg, I. et al. (2000) Pancreatic and duodenal homeobox gene 1 induces expression of insulin genes in liver and ameliorates streptozotocininduced hyperglycemia. Nat. Med. 6, 568-572.

21) Ber, I., Shternhall, K., Perl, S., Ohanuna, Z., Goldberg, I., Barshack, I. et al. (2003) Functional, persistent, and extended liver to pancreas transdifferentiation. J. Biol. Chem. 278, 31950-31957.

22) Laiosa, C.V., Stadtfeld, M., Xie, H., de AndresAguayo, L. and Graf, T. (2006) Reprogramming of committed $\mathrm{T}$ cell progenitors to macrophages and dendritic cells by $\mathrm{C} / \mathrm{EBP} \alpha$ and PU.1 transcription factors. Immunity 25, 731-744.

23) Cobaleda, C., Jochum, W. and Busslinger, M. (2007) Conversion of mature B cells into T cells by dedifferentiation to uncommitted progenitors. Nature 449, 473-477.

24) Desgraz, R. and Herrera, P.L. (2009) Pancreatic neurogenin 3-expressing cells are unipotent islet precursors. Development 136, 3567-3574.

25) Berninger, B., Costa, M.R., Koch, U., Schroeder, T., Sutor, B., Grothe, B. et al. (2007) Functional properties of neurons derived from in vitro reprogrammed postnatal astroglia. J. Neurosci. 27, 8654-8664.

26) Vierbuchen, T., Ostermeier, A., Pang, Z.P., Kokubu, Y., Südhof, T.C. and Wernig, M. (2010) Direct conversion of fibroblasts to functional neurons by defined factors. Nature 463, 1035-1041.

27) Caiazzo, M., Dell'Anno, M.T., Dvoretskova, E., Lazarevic, D., Taverna, S., Leo, D. et al. (2011) Direct generation of functional dopaminergic neurons from mouse and human fibroblasts. Nature 476, 224-227.

28) Pang, Z.P., Yang, N., Vierbuchen, T., Ostermeier, A., Fuentes, D.R., Yang, T.Q. et al. (2011) Induction of human neuronal cells by defined transcription factors. Nature 476, 220-223.

29) Pfisterer, U., Kirkeby, A., Torper, O., Wood, J., Nelander, J., Dufour, A. et al. (2011) Direct conversion of human fibroblasts to dopaminergic neurons. Proc. Natl. Acad. Sci. U.S.A. 108, 10343-10348.

30) Han, D.W., Tapia, N., Hermann, A., Hemmer, K., Höing, S., Araúzo-Bravo, M.J. et al. (2012) Direct reprogramming of fibroblasts into neural stem cells by defined factors. Cell Stem Cell 10, 465472 . 
31) Ring, K.L., Tong, L.M., Balestra, M.E., Javier, R., Andrews-Zwilling, Y., Li, G. et al. (2012) Direct reprogramming of mouse and human fibroblasts into multipotent neural stem cells with a single factor. Cell Stem Cell 11, 100-109.

32) Sheng, C., Zheng, Q., Wu, J., Xu, Z., Wang, L., Li, W. et al. (2012) Direct reprogramming of Sertoli cells into multipotent neural stem cells by defined factors. Cell Res. 22, 208-218.

33) Kim, J.J., Shin, J.H., Yu, K.R., Lee, B.C., Kang, I., Lee, J.Y. et al. (2017) Direct conversion of human umbilical cord blood into induced neural stem cells with SOX2 and HMGA2. Int. J. Stem Cells 10, 227-234.

34) Connor, B., Firmin, E., McCaughey-Chapman, A., Monk, R., Lee, K., Liot, S. et al. (2018) Conversion of adult human fibroblasts into neural precursor cells using chemically modified mRNA. Heliyon 4, e00918.

35) Xiao, D., Liu, X., Zhang, M., Zou, M., Deng, Q., Sun, D. et al. (2018) Direct reprogramming of fibroblasts into neural stem cells by single nonneural progenitor transcription factor Ptfla. Nat. Commun. 9, 2865.

36) Playne, R., Jones, K.S. and Connor, B. (2018) Generation of dopamine neuronal-like cells from induced neural precursors derived from adult human cells by non-viral expression of lineage factors. J. Stem Cells Regen. Med. 14, 34-44.

37) Ahlfors, J.E., Azimi, A., El-Ayoubi, R., Velumian, A., Vonderwalde, I., Boscher, C. et al. (2019) Examining the fundamental biology of a novel population of directly reprogrammed human neural precursor cells. Stem Cell Res. Ther. 10, $1-17$.

38) Omrani, M.R., Yaqubi, M. and Mohammadnia, A. (2018) Transcription factors in regulatory and protein subnetworks during generation of neural stem cells and neurons from direct reprogramming of non-fibroblastic cell sources. Neuroscience $\mathbf{3 8 0}$, 63-77.

39) Nishimura, K., Weichert, R.M., Liu, W., Davis, R.L. and Dabdoub, A. (2014) Generation of induced neurons by direct reprogramming in the mammalian cochlea. Neuroscience 275, 125-135.

40) Baek, S., Oh, J., Song, J., Choi, H., Yoo, J., Park, G.Y. et al. (2017) Generation of integration-free induced neurons using graphene oxide-polyethylenimine. Small 13, 1-10.

41) Pereira, M., Birtele, M., Shrigley, S., Benitez, J.A., Hedlund, E., Parmar, M. et al. (2017) Direct reprogramming of resident NG2 glia into neurons with properties of fast-spiking parvalbumin-containing interneurons. Stem Cell Rep. 9, 742-751.

42) Niu, W., Zang, T., Wang, L.L., Zou, Y. and Zhang, C.L. (2018) Phenotypic reprogramming of striatal neurons into dopaminergic neuron-like cells in the adult mouse brain. Stem Cell Rep. 11, 1156-1170.

43) Pereira, M., Birtele, M. and Ottosson, D.R. (2019) In vivo direct reprogramming of resident glial cells into interneurons by intracerebral injection of viral vectors. J. Vis. Exp. 148, e59465.
44) Matsuda, T., Irie, T., Katsurabayashi, S., Hayashi, Y., Nagai, T., Hamazaki, N. et al. (2019) Pioneer factor NeuroD1 rearranges transcriptional and epigenetic profiles to execute microglia-neuron conversion. Neuron 101, 472-485.e7.

45) Liu, Y., Xue, Y., Ridley, S., Zhang, D., Rezvani, K., $\mathrm{Fu}$, X.D. et al. (2014) Direct reprogramming of Huntington's disease patient fibroblasts into neuron-like cells leads to abnormal neurite outgrowth, increased cell death, and aggregate formation. PLoS One 9, 1-5.

46) Liu, M.-L., Zang, T. and Zhang, C.-L. (2016) Direct lineage reprogramming reveals disease-specific phenotypes of motor neurons from human ALS patients. Cell Rep. 14, 115-128.

47) Villanueva-Paz, M., Povea-Cabello, S., VillalónGarcía, I., Suárez-Rivero, J.M., ÁlvarezCórdoba, M., de la Mata, M. et al. (2019) Pathophysiological characterization of MERRF patient-specific induced neurons generated by direct reprogramming. Biochim. Biophys. Acta Mol. Cell Res. 1866, 861-881.

48) Chanda, S., Ang, C.E., Lee, Q.Y., Ghebrial, M., Haag, D., Shibuya, Y. et al. (2019) Direct reprogramming of human neurons identifies MARCKSL1 as a pathogenic mediator of valproic acid-induced teratogenicity. Cell Stem Cell 25, 103-119.e6.

49) Ieda, M., Fu, J.-D., Delgado-Olguin, P., Vedantham, V., Hayashi, Y., Bruneau, B.G. et al. (2010) Direct reprogramming of fibroblasts into functional cardiomyocytes by defined factors. Cell 142, 375-386.

50) Song, K., Nam, Y.-J., Luo, X., Qi, X., Tan, W., Huang, G.N. et al. (2012) Heart repair by reprogramming non-myocytes with cardiac transcription factors. Nature 485, 599-604.

51) Protze, S., Khattak, S., Poulet, C., Lindemann, D., Tanaka, E.M. and Ravens, U. (2012) A new approach to transcription factor screening for reprogramming of fibroblasts to cardiomyocytelike cells. J. Mol. Cell. Cardiol. 53, 323-332.

52) Wada, R., Muraoka, N., Inagawa, K., Yamakawa, H., Miyamoto, K., Sadahiro, T. et al. (2013) Induction of human cardiomyocyte-like cells from fibroblasts by defined factors. Proc. Natl. Acad. Sci. U.S.A. 110, 12667-12672.

53) Fu, J.-D., Stone, N.R., Liu, L., Spencer, C.I., Qian, L., Hayashi, Y. et al. (2013) Direct reprogramming of human fibroblasts toward a cardiomyocyte-like state. Stem Cell Rep. 1, 235-247.

54) Jayawardena, T.M., Egemnazarov, B., Finch, E.A., Zhang, L., Payne, J.A., Pandya, K. et al. (2012) MicroRNA-mediated in vitro and in vivo direct reprogramming of cardiac fibroblasts to cardiomyocytes. Circ. Res. 110, 1465-1473.

55) Sekiya, S. and Suzuki, A. (2011) Direct conversion of mouse fibroblasts to hepatocyte-like cells by defined factors. Nature 475, 390-393.

56) Huang, P., He, Z., Ji, S., Sun, H., Xiang, D., Liu, C. et al. (2011) Induction of functional hepatocytelike cells from mouse fibroblasts by defined 
factors. Nature 475, 386-391.

57) Du, Y., Wang, J., Jia, J., Song, N., Xiang, C., Xu, J. et al. (2014) Human hepatocytes with drug metabolic function induced from fibroblasts by lineage reprogramming. Cell Stem Cell 14, 394403.

58) Huang, P., Zhang, L., Gao, Y., He, Z., Yao, D., Wu, Z. et al. (2014) Direct reprogramming of human fibroblasts to functional and expandable hepatocytes. Cell Stem Cell 14, 370-384.

59) Simeonov, K.P. and Uppal, H. (2014) Direct reprogramming of human fibroblasts to hepatocyte-like cells by synthetic modified mRNAs. PLoS One 9, e100134.

60) Song, G., Pacher, M., Balakrishnan, A., Yuan, Q. Tsay, H.C., Yang, D. et al. (2016) Direct reprogramming of hepatic myofibroblasts into hepatocytes in vivo attenuates liver fibrosis. Cell Stem Cell 18, 797-808.

61) Nakamori, D., Akamine, H., Takayama, K., Sakurai, F. and Mizuguchi, H. (2017) Direct conversion of human fibroblasts into hepatocytelike cells by ATF5, PROX1, FOXA2, FOXA3, and HNF4A transduction. Sci. Rep. 7, 1-9.

62) Wu, W., Jin, Y.Q. and Gao, Z. (2017) Directly reprogramming fibroblasts into adipogenic, neurogenic and hepatogenic differentiation lineages by defined factors. Exp. Ther. Med. 13, 2685-2690.

63) Chen, C., Pla-Palacín, I., Baptista, P.M., Shang, P., Oosterhoff, L.A., van Wolferen, M.E. et al. (2018) Hepatocyte-like cells generated by direct reprogramming from murine somatic cells can repopulate decellularized livers. Biotechnol. Bioeng. 115, 2807-2816.

64) Park, S., Hwang, S.I., Kim, J., Hwang, S., Kang, S., Yang, S. et al. (2019) The therapeutic potential of induced hepatocyte-like cells generated by direct reprogramming on hepatic fibrosis. Stem Cell Res. Ther. 10, 1-11.

65) Zhou, Q., Brown, J., Kanarek, A., Rajagopal, J. and Melton, D.A. (2008) In vivo reprogramming of adult pancreatic exocrine cells to $\beta$-cells. Nature 455, 627-632.

66) Berneman-Zeitouni, D., Molakandov, K., Elgart, M., Mor, E., Fornoni, A., Domínguez, M.R. et al. (2014) The temporal and hierarchical control of transcription factors-induced liver to pancreas transdifferentiation. PLoS One 9, 1-11.

67) Yamada, T., Cavelti-Weder, C., Caballero, F., Lysy, P.A., Guo, L., Sharma, A. et al. (2015) Reprogramming mouse cells with a pancreatic duct phenotype to insulin-producing $\beta$-like cells. Endocrinology 156, 2029-2038.

68) Wang, Y., Galivo, F., Pelz, C., Haft, A., Lee, J., Kim, S.K. et al. (2016) Efficient generation of pancreatic $\beta$-like cells from the mouse gallbladder. Stem Cell Res. 17, 587-596.

69) Hill, C.M., Banga, A., Abrahante, J.E., Yuan, C., Mutch, L.A., Janecek, J. et al. (2017) Establishing a large-animal model for in vivo reprogramming of bile duct cells into insulin-secreting cells to treat diabetes. Hum. Gene Ther. Clin. Dev. 28, 87-95.
70) Yang, X.F., Ren, L.W., Yang, L., Deng, C.Y. and Li, F.R. (2017) In vivo direct reprogramming of liver cells to insulin producing cells by virus-free overexpression of defined factors. Endocr. J. 64, 291-302.

71) Liao, H.K., Hatanaka, F., Araoka, T., Reddy, P., Wu, M.Z., Sui, Y. et al. (2017) In vivo target gene activation via CRISPR/Cas9-mediated trans-epigenetic modulation. Cell 171, 1495-1507.e15.

72) Laiosa, C.V., Stadtfeld, M., Xie, H., de AndresAguayo, L. and Graf, T. (2006) Reprogramming of committed $\mathrm{T}$ cell progenitors to macrophages and dendritic cells by $\mathrm{C} / \mathrm{EBP} \alpha$ and PU.1 transcription factors. Immunity 25, 731-744.

73) Cobaleda, C., Jochum, W. and Busslinger, M. (2007) Conversion of mature B cells into T cells by dedifferentiation to uncommitted progenitors. Nature 449, 473-477.

74) Feng, R., Desbordes, S.C., Xie, H., Tillo, E.S., Pixley, F., Stanley, E.R. et al. (2008) PU.1 and $\mathrm{C} / \mathrm{EBP} \alpha / \beta$ convert fibroblasts into macrophagelike cells. Proc. Natl. Acad. Sci. U.S.A. 105, 60576062.

75) Ono, Y., Wang, Y., Suzuki, H., Okamoto, S., Ikeda, Y., Murata, M. et al. (2012) Induction of functional platelets from mouse and human fibroblasts by p45NF-E2/Maf. Blood 120, 3812-3821.

76) Suzuki, T., Nakano-Ikegaya, M., Yabukami-Okuda, H., de Hoon, M., Severin, J., Saga-Hatano, S. et al. (2012) Reconstruction of monocyte transcriptional regulatory network accompanies monocytic functions in human fibroblasts. PLoS One 7, e33474.

77) Batta, K., Florkowska, M., Kouskoff, V. and Lacaud, G. (2014) Direct reprogramming of murine fibroblasts to hematopoietic progenitor cells. Cell Rep. 9, 1871-1884.

78) Rosa, F.F., Pires, C.F., Kurochkin, I., Ferreira, A.G., Gomes, A.M., Palma, L.G. et al. (2018) Direct reprogramming of fibroblasts into antigenpresenting dendritic cells. Sci. Immunol. 3, 1-16.

79) Mizoshiri, N., Kishida, T., Yamamoto, K., Shirai, T., Terauchi, R., Tsuchida, S. et al. (2015) Transduction of Oct6 or Oct9 gene concomitant with Myc family gene induced osteoblast-like phenotypic conversion in normal human fibroblasts. Biochem. Biophys. Res. Commun. 467, 1110-1116.

80) Yamamoto, K., Kishida, T., Sato, Y., Nishioka, K., Ejima, A., Fujiwara, H. et al. (2015) Direct conversion of human fibroblasts into functional osteoblasts by defined factors. Proc. Natl. Acad. Sci. U.S.A. 112, 6152-6157.

81) Yamamoto, K., Sato, Y., Honjo, K., Ichioka, H., Oseko, F., Sowa, Y. et al. (2016) Generation of directly converted human osteoblasts that are free of exogenous gene and xenogenic protein. J. Cell. Biochem. 2545, 2538-2545.

82) Ahmed, M.F., El-Sayed, A.K., Chen, H., Zhao, R., Jin, K., Zuo, Q. et al. (2019) Direct conversion of mouse embryonic fibroblast to osteoblast cells using hLMP-3 with Yamanaka factors. Int. J. 
Biochem. Cell Biol. 106, 84-95.

83) Wakao, J., Kishida, T., Fumino, S., Kimura, K. Yamamoto, K., Kotani, S. et al. (2017) Efficient direct conversion of human fibroblasts into myogenic lineage induced by co-transduction with MYCL and MYOD1. Biochem. Biophys. Res. Commun. 488, 368-373.

84) Ito, N., Kii, I., Shimizu, N., Tanaka, H. and Takeda, S. (2017) Direct reprogramming of fibroblasts into skeletal muscle progenitor cells by transcription factors enriched in undifferentiated subpopulation of satellite cells. Sci. Rep. 7, 1-12.

85) Seko, Y., Azuma, N., Kaneda, M., Nakatani, K., Miyagawa, Y., Noshiro, Y. et al. (2012) Derivation of human differential photoreceptor-like cells from the iris by defined combinations of CRX, RX and NEUROD. PLoS One 7, e35611.

86) Seko, Y., Azuma, N., Ishii, T., Komuta, Y., Miyamoto, K., Miyagawa, Y. et al. (2014) Derivation of human differential photoreceptor cells from adult human dermal fibroblasts by defined combinations of CRX, RAX, OTX2 and NEUROD. Genes Cells 19, 198-208.

87) Kami, D., Kitani, T., Kawasaki, T. and Gojo, S. (2016) Cardiac mesenchymal progenitors differentiate into adipocytes via KLF4 and c-Myc. Cell Death Dis. 7, 1-12.

88) Chen, J.-H., Goh, K.J., Rocha, N., Groeneveld, M.P., Minic, M., Barrett, T.G. et al. (2017) Evaluation of human dermal fibroblasts directly reprogrammed to adipocyte-like cells as a metabolic disease model. Dis. Model. Mech. 10, 14111420.

89) Ji, H.Y., Atchison, L., Chen, Z., Chakraborty, S., Jung, Y., Truskey, G.A. et al. (2016) Transdifferentiation of human endothelial progenitors into smooth muscle cells. Biomaterials 85, 180 194

90) Hirai, H., Yang, B., Garcia-Barrio, M.T., Rom, O., Ma, P.X., Zhang, J. et al. (2018) Direct reprogramming of fibroblasts into smooth muscle-like cells with defined transcription factors-brief report. Arterioscler. Thromb. Vasc. Biol. 38, 21912197.

91) Zhao, Z., Xu, M., Wu, M., Ma, K., Sun, M., Tian, X. et al. (2015) Direct reprogramming of human fibroblasts into sweat gland-like cells. Cell Cycle 14, 3498-3505.

92) Yao, B., Xie, J., Liu, N., Hu, T., Song, W., Huang, S. et al. (2019) Direct reprogramming of epidermal cells toward sweat gland-like cells by defined factors. Cell Death Dis. 10, 272.

93) Fontijn, R.D., Favre, J., Naaijkens, B.A., Meinster, E., Paauw, N.J., Ragghoe, S.L. et al. (2014) Adipose tissue-derived stromal cells acquire endothelial-like features upon reprogramming with SOX18. Stem Cell Res. 13, 367-378.

94) Lee, S., Park, C., Han, J.W., Kim, J.Y., Cho, K., Kim, E.J. et al. (2017) Direct reprogramming of human dermal fibroblasts into endothelial cells using ER71/ETV2. Circ. Res. 120, 848-861.

95) Kajimura, S., Seale, P., Kubota, K., Lunsford, E.,
Frangioni, J.V., Gygi, S.P. et al. (2009) Initiation of myoblast to brown fat switch by a PRDM16-C/ EBP- $\beta$ transcriptional complex. Nature $\mathbf{4 6 0}$, $1154-1158$.

96) Buganim, Y., Itskovich, E., Hu, Y.C., Cheng, A.W., Ganz, K., Sarkar, S. et al. (2012) Direct reprogramming of fibroblasts into embryonic sertoli-like cells by defined factors. Cell Stem Cell 11, 373386.

97) Yang, R., Zheng, Y., Li, L., Liu, S., Burrows, M., Wei, Z. et al. (2014) Direct conversion of mouse and human fibroblasts to functional melanocytes by defined factors. Nat. Commun. 5, 5807 .

98) Bredenkamp, N., Ulyanchenko, S., O'Neill, K.E., Manley, N.R., Vaidya, H.J. and Blackburn, C.C. (2014) An organized and functional thymus generated from FOXN1-reprogrammed fibroblasts. Nat. Cell Biol. 16, 902-908.

99) Kaminski, M.M., Tosic, J., Kresbach, C., Engel, H., Klockenbusch, J., Müller, A.L. et al. (2016) Direct reprogramming of fibroblasts into renal tubular epithelial cells by defined transcription factors. Nat. Cell Biol. 18, 1269-1280.

100) Miura, S. and Suzuki, A. (2017) Generation of mouse and human organoid-forming intestinal progenitor cells by direct lineage reprogramming. Cell Stem Cell 21, 456-471.e5.

101) Yang, Y., Li, Z., Wu, X., Chen, H., Xu, W., Xiang, Q. et al. (2017) Direct reprogramming of mouse fibroblasts toward Leydig-like cells by defined factors. Stem Cell Rep. 8, 39-53.

102) Rhee, C., Lee, B.K., Beck, S., Le Blanc, L., Tucker, H.O. and Kim, J. (2017) Mechanisms of transcription factor-mediated direct reprogramming of mouse embryonic stem cells to trophoblast stemlike cells. Nucleic Acids Res. 45, 10103-10114.

103) Vanslambrouck, J.M., Woodard, L.E., Suhaimi, N., Williams, F.M., Howden, S.E., Wilson, S.B. et al. (2019) Direct reprogramming to human nephron progenitor-like cells using inducible piggyBac transposon expression of SNAI2-EYA1-SIX1. Kidney Int. 95, 1153-1166.

104) Kim, E.Y., Page, P., Dellefave-Castillo, L.M., McNally, E.M. and Wyatt, E.J. (2016) Direct reprogramming of urine-derived cells with inducible MyoD for modeling human muscle disease. Skelet. Muscle 6, 1-16.

105) Lee, J.J.A., Saito, T., Duddy, W., Takeda, S. and Yokota, T. (2018) Direct reprogramming of human DMD fibroblasts into myotubes for in vitro evaluation of antisense-mediated exon skipping and exons 45-55 skipping accompanied by rescue of dystrophin expression. Methods Mol. Biol. 1828, 141-150.

106) Cahan, P., Li, H., Morris, S.A., Lummertz Da Rocha, E., Daley, G.Q. and Collins, J.J. (2014) CellNet: Network biology applied to stem cell engineering. Cell 158, 903-915.

107) Tomaru, Y., Hasegawa, R., Suzuki, T., Sato, T., Kubosaki, A., Suzuki, M. et al. (2014) A transient disruption of fibroblastic transcriptional regulatory network facilitates trans-differentiation. Nu- 
cleic Acids Res. 42, 8905-8913.

108) D'Alessio, A.C., Fan, Z.P., Wert, K.J., Baranov, P., Cohen, M.A., Saini, J.S. et al. (2015) A systematic approach to identify candidate transcription factors that control cell identity. Stem Cell Rep. 5, 763-775.

109) Rackham, O.J.L., Firas, J., Fang, H., Oates, M.E., Holmes, M.L., Knaupp, A.S. et al. (2016) A predictive computational framework for direct reprogramming between human cell types. Nat. Genet. 48, 331-335.

110) Ronquist, S., Patterson, G., Muir, L.A., Lindsly, S., Chen, H., Brown, M. et al. (2017) Algorithm for cellular reprogramming. Proc. Natl. Acad. Sci. U.S.A. 114, 11832-11837.

111) Fusaki, N., Ban, H., Nishiyama, A., Saeki, K. and Hasegawa, M. (2009) Efficient induction of transgene-free human pluripotent stem cells using a vector based on Sendai virus, an RNA virus that does not integrate into the host genome. Proc. Jpn. Acad., Ser. B 85, 348-362.

112) Komuta, Y., Ishii, T., Kaneda, M., Ueda, Y., Miyamoto, K., Toyoda, M. et al. (2016) In vitro transdifferentiation of human peripheral blood mononuclear cells to photoreceptor-like cells. Biol. Open 5, 709-719.

113) Miyamoto, K., Akiyama, M., Tamura, F., Isomi, M. Yamakawa, H., Sadahiro, T. et al. (2018) Direct in vivo reprogramming with Sendai virus vectors improves cardiac function after myocardial infarction. Cell Stem Cell 22, 91-103.e5.

114) Katayama, H., Yasuchika, K., Miyauchi, Y., Kojima, H., Yamaoka, R., Kawai, T. et al. (2017) Generation of non-viral, transgene-free hepatocyte like cells with piggyBac transposon. Sci. Rep. 7, 1-10.

115) Yoon, S., Kang, K., Cho, Y.D., Kim, Y., Buisson, E.M., Yim, J.H. et al. (2018) Nonintegrating direct conversion using mRNA into hepatocytelike cells. Biomed Res. Int. 2018, 1-8.

116) Lee, K., Yu, P., Lingampalli, N., Kim, H.J., Tang, R. and Murthy, N. (2015) Peptide-enhanced mRNA transfection in cultured mouse cardiac fibroblasts and direct reprogramming towards cardiomyocyte-like cells. Int. J. Nanomedicine 10, 1841-1854.

117) Van Pham, P., Vu, N.B., Dao, T.T.T., Le, H.T.N., Phi, L.T. and Phan, N.K. (2017) Production of endothelial progenitor cells from skin fibroblasts by direct reprogramming for clinical usages. In Vitro Cell. Dev. Biol. Anim. 53, 207-216.

118) Kim, B.E., Choi, S.W., Shin, J.H., Kim, J.J., Kang, I., Lee, B.C. et al. (2018) Single-factor SOX2 mediates direct neural reprogramming of human mesenchymal stem cells via transfection of in vitro transcribed mRNA. Cell Transplant. 27, 11541167.

119) Yu, Q., Chen, J., Deng, W., Cao, X., AduFrimpong, M., Yu, J. et al. (2017) Neural differentiation of fibroblasts induced by intracellular co-delivery of Ascl1, Brn2 and FoxA1 via a nonviral vector of cationic polysaccharide. Biomed.
Mater. 13, 015022.

120) Yu, Q., Chen, J., Deng, W., Cao, X., Wang, Y., Zhou, J. et al. (2017) Direct reprogramming of mouse fibroblasts into neural cells via Porphyra yezoensis polysaccharide based high efficient gene co-delivery. J. Nanobiotech. 15, 1-15.

121) Poulou, M., Mandalos, N.P., Karnavas, T., Saridaki, M., McKay, R.D.G. and Remboutsika, E.A. (2016) "hit and run" approach to inducible direct reprogramming of astrocytes to neural stem cells. Front. Physiol. 7, 1-5.

122) Dai, S.B., Shen, T., Zheng, T.T., Pu, J.L. and Chen, X.Z. (2019) Plasmid-based generation of neural cells from human fibroblasts using non-integrating episomal vectors. Neural Regen. Res. 14, 501-505.

123) Fu, Y., Huang, C., Xu, X., Gu, H., Ye, Y., Jiang, C. et al. (2015) Direct reprogramming of mouse fibroblasts into cardiomyocytes with chemical cocktails. Cell Res. 25, 1013-1024.

124) Han, Y.C., Lim, Y., Duffieldl, M.D., Li, H., Liu, J., Abdul Manaph, N.P. et al. (2016) Direct reprogramming of mouse fibroblasts to neural stem cells by small molecules. Stem Cells Int. 2016, 4304916.

125) Hu, W., Qiu, B., Guan, W., Wang, Q., Wang, M., Li, W. et al. (2015) Direct conversion of normal and Alzheimer's disease human fibroblasts into neuronal cells by small molecules. Cell Stem Cell 17, 204-212.

126) Li, X., Zuo, X., Jing, J., Ma, Y., Wang, J., Liu, D. et al. (2015) Small-molecule-driven direct reprogramming of mouse fibroblasts into functional neurons. Cell Stem Cell 17, 195-203.

127) Tang, W., Guo, R., Shen, S.-J., Zheng, Y., Lu, Y.-T., Jiang, M.-M. et al. (2019) Chemical cocktails enable hepatic reprogramming of human urine-derived cells with a single transcription factor. Acta Pharmacol. Sin. 40, 620-629.

128) Bar-Nur, O., Gerli, M.F.M., Di Stefano, B., Almada, A.E., Galvin, A., Coffey, A. et al. (2018) Direct reprogramming of mouse fibroblasts into functional skeletal muscle progenitors. Stem Cell Rep. 10, 1505-1521.

129) Lee, C., Robinson, M. and Willerth, S.M. (2018) Direct reprogramming of glioblastoma cells into neurons using small molecules. ACS Chem. Neurosci. 9, 3175-3185.

130) Liu, M.L., Zang, T., Zou, Y., Chang, J.C., Gibson, J.R., Huber, K.M. et al. (2013) Small molecules enable neurogenin 2 to efficiently convert human fibroblasts into cholinergic neurons. Nat. Commun. 4, 2183.

131) Zheng, J., Choi, K.A., Kang, P.J., Hyeon, S., Kwon, S., Moon, J.H. et al. (2016) A combination of small molecules directly reprograms mouse fibroblasts into neural stem cells. Biochem. Biophys. Res. Commun. 476, 42-48.

132) Thier, M.C., Hommerding, O., Panten, J., Pinna, R., García-González, D., Berger, T. et al. (2019) Identification of embryonic neural plate border stem cells and their generation by direct reprogramming from adult human blood cells. Cell Stem 
Cell 24, 166-182.e13.

133) Herdy, J., Schafer, S., Kim, Y., Ansari, Z., Zangwill, D., Ku, M. et al. (2019) Chemical modulation of transcriptionally enriched signaling pathways to optimize the conversion of fibroblasts into neurons. eLife 8, 1-21.

134) Sapir, T., Shternhall, K., Meivar-Levy, I., Blumenfeld, T., Cohen, H., Skutelsky, E. et al. (2005) Cell-replacement therapy for diabetes: Generating functional insulin-producing tissue from adult human liver cells. Proc. Natl. Acad. Sci. U.S.A. 102, 7964-7969.

135) Szabo, E., Rampalli, S., Risueño, R.M., Schnerch, A., Mitchell, R., Fiebig-Comyn, A. et al. (2010) Direct conversion of human fibroblasts to multilineage blood progenitors. Nature 468, 521-526.

136) Efe, J.A., Hilcove, S., Kim, J., Zhou, H., Ouyang, K., Wang, G. et al. (2011) Conversion of mouse fibroblasts into cardiomyocytes using a direct reprogramming strategy. Nat. Cell Biol. 13, $215-222$.

137) Matsui, T., Takano, M., Yoshida, K., Ono, S., Fujisaki, C., Matsuzaki, Y. et al. (2012) Neural stem cells directly differentiated from partially reprogrammed fibroblasts rapidly acquire gliogenic competency. Stem Cells 30, 1109-1119.

138) Capetian, P., Azmitia, L., Pauly, M.G., Krajka, V., Stengel, F., Bernhardi, E.M. et al. (2016) Plasmidbased generation of induced neural stem cells from adult human fibroblasts. Front. Cell. Neurosci. 10, $1-12$.

139) Ginsberg, M., James, D., Ding, B.-S., Nolan, D. Geng, F., Butler, J.M. et al. (2012) Efficient direct reprogramming of mature amniotic cells into endothelial cells by ETS factors and TGF $\beta$ suppression. Cell 151, 559-575.

140) Kim, Y.J., Lim, H., Li, Z., Oh, Y., Kovlyagina, I., Choi, I.Y. et al. (2014) Generation of multipotent induced neural crest by direct reprogramming of human postnatal fibroblasts with a single transcription factor. Cell Stem Cell 15, 497-506.

141) Kim, J.B., Lee, H., Araúzo-Bravo, M.J., Hwang, K., Nam, D., Park, M.R. et al. (2015) Oct4-induced oligodendrocyte progenitor cells enhance functional recovery in spinal cord injury model. EMBO J. 34, 2971-2983.

142) Iacovides, D., Rizki, G., Lapathitis, G. and Strati, K. (2016) Direct conversion of mouse embryonic fibroblasts into functional keratinocytes through transient expression of pluripotency-related genes. Stem Cell Res. Ther. 7, 1-12.

143) Xue, Y., Ouyang, K., Huang, J., Zhou, Y., Ouyang, H., Li, H. et al. (2013) Direct conversion of fibroblasts to neurons by reprogramming PTBregulated microRNA circuits. Cell 152, 82-96.

144) Yu, K.R., Shin, J.H., Kim, J.J., Koog, M.G., Lee, J.Y., Choi, S.W. et al. (2015) Rapid and efficient direct conversion of human adult somatic cells into neural stem cells by HMGA2/let-7b. Cell Rep. 10, 441-452.

145) Abernathy, D.G., Kim, W.K., McCoy, M.J., Lake, A.M., Ouwenga, R., Lee, S.W. et al. (2017)
MicroRNAs induce a permissive chromatin environment that enables neuronal subtype-specific reprogramming of adult human fibroblasts. Cell Stem Cell 21, 332-348.e9.

146) Liang, X.G., Tan, C., Wang, C.K., Tao, R.R., Huang, Y.J., Ma, K.F. et al. (2018) Myt1l induced direct reprogramming of pericytes into cholinergic neurons. CNS Neurosci. Ther. 24, 801-809.

147) Jayawardena, T.M., Egemnazarov, B., Finch, E.A., Zhang, L., Alan Payne, J., Pandya, K. et al. (2012) MicroRNA-mediated in vitro and in vivo direct reprogramming of cardiac fibroblasts to cardiomyocytes. Circ. Res. 110, 1465-1473.

148) Muraoka, N., Yamakawa, H., Miyamoto, K., Sadahiro, T., Umei, T., Isomi, M. et al. (2014) MiR-133 promotes cardiac reprogramming by directly repressing Snai1 and silencing fibroblast signatures. EMBO J. 33, 1565-1581.

149) Bektik, E., Dennis, A., Prasanna, P., Madabhushi, A. and Fu, J.D. (2017) Single cell qPCR reveals that additional HAND2 and microRNA-1 facilitate the early reprogramming progress of sevenfactor-induced human myocytes. PLoS One 12, $1-16$.

150) Huang, X., Trinh, T., Aljoufi, A. and Broxmeyer, H.E. (2018) Hypoxia signaling pathway in stem cell regulation: Good and Evil. Curr. Stem Cell Rep. 4, 149-157.

151) Van Pham, P., Vu, N.B., Nguyen, H.T., Huynh, O.T. and Truong, M.T.H. (2016) Significant improvement of direct reprogramming efficacy of fibroblasts into progenitor endothelial cells by ETV2 and hypoxia. Stem Cell Res. Ther. 7, 1-10.

152) Wang, Y., Shi, S., Liu, H. and Meng, L. (2016) Hypoxia enhances direct reprogramming of mouse fibroblasts to cardiomyocyte-like cells. Cell. Reprogram. 18, 1-7.

153) Kulangara, K., Adler, A.F., Wang, H., Chellappan, M., Hammett, E., Yasuda, R. et al. (2014) The effect of substrate topography on direct reprogramming of fibroblasts to induced neurons. Biomaterials 35, 5327-5336.

154) Morez, C., Noseda, M., Paiva, M.A., Belian, E., Schneider, M.D. and Stevens, M.M. (2015) Enhanced efficiency of genetic programming toward cardiomyocyte creation through topographical cues. Biomaterials 70, 94-104.

155) Yoo, J., Noh, M., Kim, H., Jeon, N.L., Kim, B.S. and Kim, J. (2015) Nanogrooved substrate promotes direct lineage reprogramming offibroblasts to functional induced dopaminergic neurons. Biomaterials 45, 36-45.

156) Sia, J., Yu, P., Srivastava, D. and Li, S. (2016) Effect of biophysical cues on reprogramming to cardiomyocytes. Biomaterials 103, 1-11.

157) Lee, G.S., Kim, M.G. and Kwon, H.J. (2019) Electrical stimulation induces direct reprogramming of human dermal fibroblasts into hyaline chondrogenic cells. Biochem. Biophys. Res. Commun. 513, 990-996.

158) Black, J.B., Adler, A.F., Wang, H.G., D'Ippolito, A.M., Hutchinson, H.A., Reddy, T.E. et al. (2016) 
Targeted epigenetic remodeling of endogenous loci by CRISPR/Cas9-based transcriptional activators directly converts fibroblasts to neuronal cells. Cell Stem Cell 19, 406-414.

159) Hirai, H., Katoku-Kikyo, N., Keirstead, S.A. and Kikyo, N. (2013) Accelerated direct reprogramming of fibroblasts into cardiomyocyte-like cells with the MyoD transactivation domain. Cardiovasc. Res. 100, 105-113.

160) Gascón, S., Ortega, F. and Götz, M. (2017) Transient CREB-mediated transcription is key in direct neuronal reprogramming. Neurogenesis 4, e1285383.

161) Papadimou, E., Morigi, M., Iatropoulos, P., Xinaris, C., Tomasoni, S., Benedetti, V. et al. (2015) Direct reprogramming of human bone marrow stromal cells into functional renal cells using cellfree extracts. Stem Cell Rep. 4, 685-698.

162) Zhao, Y., Londono, P., Cao, Y., Sharpe, E.J., Proenza, C., O'Rourke, R. et al. (2015) Highefficiency reprogramming of fibroblasts into cardiomyocytes requires suppression of pro-fibrotic signalling. Nat. Commun. 6, 8243.

163) Koblas, T., Leontovyc, I., Loukotova, S., Kosinova, L. and Saudek, F. (2016) Reprogramming of Pancreatic Exocrine Cells AR42J Into Insulinproducing Cells Using mRNAs for Pdx1, Ngn3, and MafA Transcription Factors. Mol. Ther. Nucleic Acids 5, e320.

164) Li, Y., Dal-Pra, S., Mirotsou, M., Jayawardena, T.M., Hodgkinson, C.P., Bursac, N. et al. (2016) Tissue-engineered 3-dimensional (3D) microenvironment enhances the direct reprogramming of fibroblasts into cardiomyocytes by microRNAs. Sci. Rep. 6, 1-11.

165) Wang, X., Hodgkinson, C.P., Lu, K., Payne, A.J., Pratt, R.E. and Dzau, V.J. (2016) Selenium augments microRNA directed reprogramming of fibroblasts to cardiomyocytes via Nanog. Sci. Rep. 6, $1-10$.

166) Cairns, D.M., Chwalek, K., Moore, Y.E., Kelley, M.R., Abbott, R.D., Moss, S. et al. (2016) Expandable and rapidly differentiating human induced neural stem cell lines for multiple tissue engineering applications. Stem Cell Rep. 7, 557570 .

167) Zhou, H., Morales, M.G., Hashimoto, H., Dickson, M.E., Song, K., Ye, W. et al. (2017) ZNF281 enhances cardiac reprogramming by modulating cardiac and inflammatory gene expression. Genes Dev. 31, 1770-1783.

168) Sutcliffe, M.D., Tan, P.M., Fernandez-Perez, A., Nam, Y.J., Munshi, N.V. and Saucerman, J.J. (2018) High content analysis identifies unique morphological features of reprogrammed cardiomyocytes. Sci. Rep. 8, 1-11.

169) Sauls, K., Greco, T.M., Wang, L., Zou, M., Villasmil, M., Qian, L. et al. (2018) Initiating events in direct cardiomyocyte reprogramming. Cell Rep. 22, 1913-1922.

170) Bektik, E., Dennis, A., Pawlowski, G., Zhou, C., Maleski, D., Takahashi, S. et al. (2018) S-phase synchronization facilitates the early progression of induced-cardiomyocyte reprogramming through enhanced cell-cycle exit. Int. J. Mol. Sci. 19, 1364.

171) Zhou, Y., Alimohamadi, S., Wang, L., Liu, Z., Wall, J.B., Yin, C. et al. (2018) A loss of function screen of epigenetic modifiers and splicing factors during early stage of cardiac reprogramming. Stem Cells Int. 2018, 6-16.

172) Hashimoto, H., Wang, Z., Garry, G.A., Malladi, V.S., Botten, G.A., Ye, W. et al. (2019) Cardiac reprogramming factors synergistically activate genome-wide cardiogenic stage-specific enhancers. Cell Stem Cell 25, 69-86.e5.

173) Nam, Y.J., Lubczyk, C., Bhakta, M., Zang, T., Fernandez-Perez, A., McAnally, J. et al. (2014) Induction of diverse cardiac cell types by reprogramming fibroblasts with cardiac transcription factors. Development 141, 4267-4278.

174) Zhao, Y., Londono, P., Cao, Y., Sharpe, E.J., Proenza, C., O'Rourke, R. et al. (2015) Highefficiency reprogramming of fibroblasts into cardiomyocytes requires suppression of pro-fibrotic signalling. Nat. Commun. 6, 8243.

175) Zhou, Y., Wang, L., Vaseghi, H.R., Liu, Z., Lu, R., Alimohamadi, S. et al. (2016) Bmil is a key epigenetic barrier to direct cardiac reprogramming. Cell Stem Cell 18, 382-395.

176) Rastegar-Pouyani, S., Khazaei, N., Wee, P., Yaqubi, M. and Mohammadnia, A. (2017) Metaanalysis of transcriptome regulation during induction to cardiac myocyte fate from mouse and human fibroblasts. J. Cell. Physiol. 232, 20532062.

177) Dal-Pra, S., Hodgkinson, C.P., Mirotsou, M., Kirste, I. and Dzau, V.J. (2017) Demethylation of H3K27 is essential for the induction of direct cardiac reprogramming by MIR combo. Circ. Res. 120, 1403-1413.

178) Fernandez-Perez, A. and Munshi, N.V. (2017) Assessing cardiomyocyte subtypes following transcription factor-mediated reprogramming of mouse embryonic fibroblasts. J. Vis. Exp. 121, e55456.

179) Talkhabi, M., Razavi, S.M. and Salari, A. (2017) Global transcriptomic analysis of induced cardiomyocytes predicts novel regulators for direct cardiac reprogramming. J. Cell Commun. Signal. 11, 193-204.

180) Khazaei, N., Rastegar-Pouyani, S., O'Toole, N., Wee, P., Mohammadnia, A. and Yaqubi, M. (2018) Regulating the transcriptomes that mediate the conversion of fibroblasts to various nervous system neural cell types. J. Cell. Physiol. 233, 3603-3614.

181) Karow, M., Gray Camp, J., Falk, S., Gerber, T., Pataskar, A., Gac-Santel, M. et al. (2018) Direct pericyte-to-neuron reprogramming via unfolding of a neural stem cell-like program. Nat. Neurosci. 21, 932-940.

182) Luo, C., Lee, Q.Y., Wapinski, O., Castanon, R., Nery, J.R., Mall, M. et al. (2019) Global DNA methylation remodeling during direct reprogram- 
ming of fibroblasts to neurons. eLife 8, 1-19.

183) Hu, X., Qin, S., Huang, X., Yuan, Y., Tan, Z., Gu, Y. et al. (2019) Region-restrict astrocytes exhibit heterogeneous susceptibility to neuronal reprogramming. Stem Cell Rep. 12, 290-304.

184) Ruetz, T., Pfisterer, U., Di Stefano, B., Ashmore, J. Beniazza, M., Tian, T.V. et al. (2017) Constitutively active SMAD2/3 are broad-scope potentiators of transcription-factor-mediated cellular reprogramming. Cell Stem Cell 21, 791-805.e9.

185) Potts, M.B., Siu, J.J., Price, J.D., Salinas, R.D., Cho, M.J., Ramos, A.D. et al. (2014) Analysis of Mll1 deficiency identifies neurogenic transcriptional modules and brn 4 as a factor for direct astrocyte-to-neuron reprogramming. Neurosurgery $\mathbf{7 5}, 472-482$.

186) Rodríguez-Traver, E., Solís, O., Díaz-Guerra, E., Ortiz, Ó., Vergaño-Vera, E., Méndez-Gómez, H.R. et al. (2016) Role of Nurr1 in the generation and differentiation of dopaminergic neurons from stem cells. Neurotox. Res. 30, 14-31.

187) Treutlein, B., Lee, Q.Y., Camp, J.G., Mall, M., Koh, W., Shariati, S.A.M. et al. (2016) Dissecting direct reprogramming from fibroblast to neuron using single-cell RNA-seq. Nature 534, 391-395.

188) Wapinski, O.L., Lee, Q.Y., Chen, A.C., Li, R. Corces, M.R., Ang, C.E. et al. (2017) Rapid chromatin switch in the direct reprogramming of fibroblasts to neurons. Cell Rep. 20, 3236-3247.

189) Wu, Z.T., Yao, D., Ji, S.Y., Ni, X., Gao, Y.M., Hui, L.J. et al. (2016) Optimized hepatocyte-like cells with functional drug transporters directly-reprogrammed from mouse fibroblasts and their potential in drug disposition and toxicology. Cell. Physiol. Biochem. 38, 1815-1830.

190) Serrano, F., García-Bravo, M., Blazquez, M., Torres, J., Castell, J.V., Segovia, J.C. et al. (2016) Silencing of hepatic fate-conversion factors induce tumorigenesis in reprogrammed hepatic progenitor-like cells. Stem Cell Res. Ther. 7, 1-15.

191) Rastegar-Pouyani, S., Khazaei, N., Wee, P., Mohammadnia, A. and Yaqubi, M. (2016) Role of hepatic-specific transcription factors and polycomb repressive complex 2 during induction of fibroblasts to hepatic fate. PLoS One 11, 1-20.

192) Biddy, B.A., Kong, W., Kamimoto, K., Guo, C. Waye, S.E., Sun, T. et al. (2018) Single-cell mapping of lineage and identity in direct reprogramming. Nature 564, 219-224.

193) Winiecka-Klimek, M., Smolarz, M., Walczak, M.P., Zieba, J., Hulas-Bigoszewska, K., Kmieciak, B. et al. (2015) SOX2 and SOX2-MYC reprogramming process of fibroblasts to the neural stem cells compromised by senescence. PLoS One $\mathbf{1 0}$ e0141688.

194) Kim, S.M., Lim, K.T., Kwak, T.H., Lee, S.C., Im, J.H., Hali, S. et al. (2016) Induced neural stem cells from distinct genetic backgrounds exhibit different reprogramming status. Stem Cell Res. 16, 460-468.

195) Masserdotti, G., Gillotin, S., Sutor, B., Drechsel, D., Irmler, M., Jørgensen, H.F. et al. (2015) Tran- scriptional mechanisms of proneural factors and REST in regulating neuronal reprogramming of astrocytes. Cell Stem Cell 17, 74-88.

196) Fukuda, T., Ishizawa, Y., Donai, K., Sugano, E. and Tomita, H. (2018) The poly-cistronic expression of four transcriptional factors (CRX, RAX, NEURO-D, OTX2) in fibroblasts via retro- or lentivirus causes partial reprogramming into photoreceptor cells. Cell Biol. Int. 42, 608-614.

197) Cohen, H., Barash, H., Meivar-Levy, I., Molakandov, K., Ben-Shimon, M., Gurevich, M. et al. (2018) The Wnt/ $\beta$-catenin pathway determines the predisposition and efficiency of liver-topancreas reprogramming. Hepatology 68, 15891603.

198) Lagies, S., Pichler, R., Kaminski, M.M., Schlimpert, M., Walz, G., Lienkamp, S.S. et al. (2018) Metabolic characterization of directly reprogrammed renal tubular epithelial cells (iRECs). Sci. Rep. 8, 1-12.

199) Sadahiro, T., Isomi, M., Muraoka, N., Kojima, H., Haginiwa, S., Kurotsu, S. et al. (2018) Tbx6 induces nascent mesoderm from pluripotent stem cells and temporally controls cardiac versus somite lineage diversification. Cell Stem Cell 23, 382-395.e5.

200) Akbari, B., Wee, P., Yaqubi, M. and Mohammadnia, A. (2017) Comprehensive transcriptome mining of the direct conversion of mesodermal cells. Sci. Rep. 7, 1-13.

201) Morris, S.A. (2016) Direct lineage reprogramming via pioneer factors; a detour through developmental gene regulatory networks. Development 143, 2696-2705.

202) Wapinski, O.L., Vierbuchen, T., Qu, K., Lee, Q.Y., Chanda, S., Fuentes, D.R. et al. (2013) Hierarchical mechanisms for direct reprogramming of fibroblasts to neurons. Cell 155, 621-635.

203) Buenrostro, J.D., Wu, B., Litzenburger, U.M., Ruff, D., Gonzales, M.L., Snyder, M.P. et al. (2015) Single-cell chromatin accessibility reveals principles of regulatory variation. Nature 523, 486-490.

204) Harada, A., Maehara, K., Handa, T., Arimura, Y., Nogami, J., Hayashi-Takanaka, Y. et al. (2019) A chromatin integration labelling method enables epigenomic profiling with lower input. Nat. Cell Biol. 21, 287-296.

205) Hainer, S.J., Bošković, A., McCannell, K.N., Rando, O.J. and Fazzio, T.G. (2019) Profiling of pluripotency factors in single cells and early embryos. Cell 177, 1319-1329.e11.

206) Nagano, T., Lubling, Y., Stevens, T.J., Schoenfelder, S., Yaffe, E., Dean, W. et al. (2013) Single-cell Hi-C reveals cell-to-cell variability in chromosome structure. Nature 502, 5964.

207) Rubio, A., Luoni, M., Giannelli, S.G., Radice, I., Iannielli, A., Cancellieri, C. et al. (2016) Rapid and efficient CRISPR/Cas9 gene inactivation in human neurons during human pluripotent stem cell differentiation and direct reprogramming. Sci. Rep. 6, 1-16. 
208) Singh, V.P., Mathison, M., Patel, V., Sanagasetti, D., Gibson, B.W., Yang, J. et al. (2016) MiR-590 promotes transdifferentiation of porcine and human fibroblasts toward a cardiomyocyte-like fate by directly repressing specificity protein 1 . J. Am. Heart Assoc. 5, e003922.

209) Palazzolo, G., Quattrocelli, M., Toelen, J., Dominici, R., Anastasia, L., Tettamenti, G. et al. (2016) Cardiac niche influences the direct reprogramming of canine fibroblasts into cardiomyocytelike cells. Stem Cells Int. 2016, 4969430.

210) Guo, Y., Yu, T., Lei, L., Duan, A., Ma, X. and Wang, H. (2017) Conversion of goat fibroblasts into lineage-specific cells using a direct reprogramming strategy. Anim. Sci. J. 88, 745-754.

211) Zhou, Z., Kohda, K., Ibata, K., Kohyama, J., Akamatsu, W., Yuzaki, M. et al. (2014) Reprogramming non-human primate somatic cells into functional neuronal cells by defined factors. Mol. Brain 7, 1-11.

212) Marro, S., Pang, Z.P., Yang, N., Tsai, M.C., Qu, K., Chang, H.Y. et al. (2011) Direct lineage conversion of terminally differentiated hepatocytes to functional neurons. Cell Stem Cell 9, 374-382.

213) Heinrich, C., Blum, R., Gascón, S., Masserdotti, G., Tripathi, P., Sánchez, R. et al. (2010) Directing astroglia from the cerebral cortex into subtype specific functional neurons. PLoS Biol. 8, e1000373.

214) Liu, X.J., Huang, Q., Li, F. and Li, C.Y. (2014) Enhancing the efficiency of direct reprogramming of human primary fibroblasts into dopaminergic neuron-like cells through p53 suppression. Sci. Chn. Life Sci. 57, 867-875.

215) Tian, C., Li, Y., Huang, Y., Wang, Y., Chen, D. Liu, J. et al. (2015) Selective generation of dopaminergic precursors from mouse fibroblasts by direct lineage conversion. Sci. Rep. 5, 1-14.

216) Yu, Q., Chen, J., Deng, W., Cao, X., AduFrimpong, M., Yu, J. et al. (2017) Neural differentiation of fibroblasts induced by intracellular co-delivery of Ascl1, Brn2 and FoxA1 via a nonviral vector of cationic polysaccharide. Biomed. Mater. 13, 015022.

217) Hao, L., Xu, Z., Sun, H., Luo, W., Yan, Y., Wang, J. et al. (2017) Direct induction of functional neuronal cells from fibroblast-like cells derived from adult human retina. Stem Cell Res. 23, 61-72.
218) Chuang, W., Sharma, A., Shukla, P., Li, G., Mall, M., Rajarajan, K. et al. (2017) Partial reprogramming of pluripotent stem cell-derived cardiomyocytes into neurons. Sci. Rep. 7, 1-10.

219) Zhang, Q.J., Li, J.J., Lin, X., Lu, Y.Q., Guo, X.X., Dong, E.L. et al. (2017) Modeling the phenotype of spinal muscular atrophy by the direct conversion of human fibroblasts to motor neurons. Oncotarget 8, 10945-10953.

220) Noda, T., Meas, S.J., Nogami, J., Amemiya, Y., Uchi, R., Ohkawa, Y. et al. (2018) Direct reprogramming of spiral ganglion non-neuronal cells into neurons: Toward ameliorating sensorineural hearing loss by gene therapy. Front. Cell Dev. Biol. 6. 1-14.

221) Araújo, J.A. de M., Hilscher, M.M., MarquesCoelho, D., Golbert, D.C.F., Cornelio, D.A., Batistuzzo de Medeiros, S.R. et al. (2018) Direct reprogramming of adult human somatic stem cells into functional neurons using Sox2, Ascl1, and Neurog2. Front. Cell. Neurosci. 12, 1-15.

222) Li, S., Shi, Y., Yao, X., Wang, X., Shen, L., Rao, Z. et al. (2019) Conversion of astrocytes and fibroblasts into functional noradrenergic neurons. Cell Rep. 28, 682-697.e7.

223) Sadahira, K., Fukuchi, Y., Kunimono, H., Sakurai, M., Ikeda, Y., Okamoto, S. et al. (2012) Direct reprogramming of terminally differentiated B cells into erythroid lineage. FEBS Lett. 586, 36453652 .

224) Outani, H., Okada, M., Yamashita, A., Nakagawa, K., Yoshikawa, H. and Tsumaki, N. (2013) Direct induction of chondrogenic cells from human dermal fibroblast culture by defined factors. PLoS One 8, e77365.

225) Qin, M., Chen, R., Li, H., Liang, H., Xue, Q., Li, F. et al. (2016) Direct reprogramming of human amniotic fluid stem cells by OCT4 and application in repairing of cerebral ischemia damage. Int. J. Biol. Sci. 12, 558-568.

226) Zhu, S., Rezvani, M., Harbell, J., Mattis, A.N., Wolfe, A.R., Benet, L.Z. et al. (2014) Mouse liver repopulation with hepatocytes generated from human fibroblasts. Nature 508, 93-97.

(Received Jan. 9, 2020; accepted Feb. 21, 2020) 


\section{Profile}

Kenichi Horisawa was born in Tochigi prefecture, Japan, and graduated from University of Tsukuba in 1997. After 2 years in a scientific publishing company, he entered the Graduate School of Science and Technology, Keio University, and received his Ph.D. degree under the supervision of Prof. Hiroshi Yanagawa in 2005. He worked as a postdoctoral fellow in Prof. Hiroshi Yanagawa's laboratory from 2005 to 2010, and as an Assistant Professor in Prof. Nobuhide Doi's laboratory from 2010 to 2013 in the Faculty of Science and Technology, Keio University. In 2013, he joined Prof. Atsushi Suzuki's laboratory at the Medical Institute of Bioregulation, Kyushu University, as an Assistant Professor. His research interests are molecular mechanisms for the regeneration and direct reprogramming of hepatic cells, primarily on the molecular function and

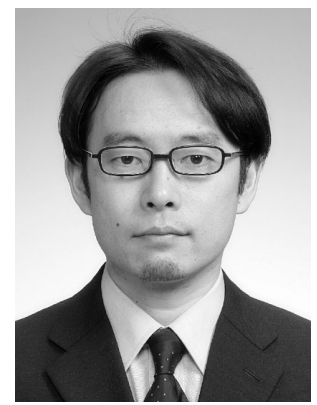
behavior of the master transcription factors for hepatic development.

\section{Profile}

Atsushi Suzuki was born in Gunma prefecture, Japan, in 1974 and graduated from Tohoku University in 1998. Then, he moved to University of Tsukuba with an aim to contribute to the development of innovative medicine using the knowledge and experience obtained from the study of basic biology. Subsequently, he succeeded in the prospective isolation of hepatic stem cells from the developing mouse liver and unraveled the mechanisms controlling the properties of hepatic stem cells during liver development. He made his Ph.D. thesis defense in the summer of 2002 and then spent time at the Salk Institute for Biological Studies, San Diego, U.S.A., to learn novel experimental techniques. After being awarded his Ph.D. from University of Tsukuba in March 2003, he continued his work at the Salk Institute until returning to RIKEN/CDB in Japan in

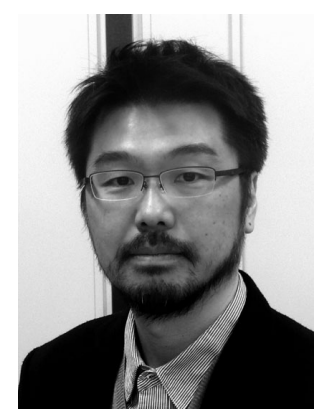
2005. Two and half years later, he moved to Kyushu University to join the tenure track program of "Kyushu University Research Superstar Program (SSP)" and became a principal investigator in his own laboratory. In that time, he decided to start new research projects, and finally succeeded in the induction of direct conversion of skinderived fibroblasts to hepatocytes using defined transcription factors. He subsequently became an Associate Professor in 2011 and then Professor at Kyushu University in 2013. His ongoing studies are focused on not only liver development, regeneration, and diseases but also the determination and conversion of the fate of cells in various digestive organs, with the hope that these will provide new insights into therapies for diseases in organs of the digestive system. 